\title{
Modelling the climate and surface mass balance of polar ice sheets using RACMO2 - Part 2: Antarctica (1979-2016)
}

\author{
Jan Melchior van Wessem ${ }^{1}$, Willem Jan van de Berg ${ }^{1}$, Brice P. Y. Noë ${ }^{1}$, Erik van Meijgaard ${ }^{2}$, Charles Amory ${ }^{3}$, \\ Gerit Birnbaum $^{4}$, Constantijn L. Jakobs ${ }^{1}$, Konstantin Krüger ${ }^{4}$, Jan T. M. Lenaerts ${ }^{5}$, Stef Lhermitte ${ }^{6}$, \\ Stefan R. M. Ligtenberg ${ }^{1}$, Brooke Medley ${ }^{7}$, Carleen H. Reijmer ${ }^{1},{\text { Kristof van } \text { Tricht }^{8} \text {, Luke D. Trusel }}^{9}$, \\ Lambertus H. van Ulft ${ }^{2}$, Bert Wouters ${ }^{1}$, Jan Wuite ${ }^{10}$, and Michiel R. van den Broeke ${ }^{1}$ \\ ${ }^{1}$ Institute for Marine and Atmospheric Research Utrecht, Utrecht University, Utrecht, the Netherlands \\ ${ }^{2}$ Royal Netherlands Meteorological Institute, De Bilt, the Netherlands \\ ${ }^{3}$ Department of Geography, University of Liege, Liege, Belgium \\ ${ }^{4}$ Alfred Wegener Institute, Helmholtz Centre for Polar and Marine Research, Bremerhaven, Germany \\ ${ }^{5}$ Department of Atmospheric and Oceanic Sciences, University of Colorado, Boulder CO, USA \\ ${ }^{6}$ Department of Geoscience and Remote Sensing, Delft University of Technology, Delft, The Netherlands \\ ${ }^{7}$ Cryospheric Sciences Laboratory, NASA Goddard Space Flight Center, Greenbelt, MD, USA \\ ${ }^{8}$ KU Leuven, Department of Earth and Environmental Sciences, Leuven, Belgium \\ ${ }^{9}$ Department of Geology, Rowan University, Glassboro, New Jersey, USA \\ ${ }^{10}$ ENVEO IT GmbH, Innsbruck, Austria
}

Correspondence: Jan Melchior van Wessem (j.m.vanwessem@uu.nl)

Received: 8 September 2017 - Discussion started: 9 October 2017

Revised: 22 February 2018 - Accepted: 26 February 2018 - Published: 20 April 2018

\begin{abstract}
We evaluate modelled Antarctic ice sheet (AIS) near-surface climate, surface mass balance (SMB) and surface energy balance (SEB) from the updated polar version of the regional atmospheric climate model, RACMO2 (19792016). The updated model, referred to as RACMO2.3p2, incorporates upper-air relaxation, a revised topography, tuned parameters in the cloud scheme to generate more precipitation towards the AIS interior and modified snow properties reducing drifting snow sublimation and increasing surface snowmelt.

Comparisons of RACMO2 model output with several independent observational data show that the existing biases in AIS temperature, radiative fluxes and SMB components are further reduced with respect to the previous model version. The model-integrated annual average SMB for the ice sheet including ice shelves (minus the Antarctic Peninsula, AP) now amounts to $2229 \mathrm{Gty}^{-1}$, with an interannual variability of $109 \mathrm{Gt}^{-1}$. The largest improvement is found in modelled surface snowmelt, which now compares well with satellite and weather station observations. For the high-resolution $(\sim 5.5 \mathrm{~km})$ AP simulation, results remain comparable to earlier studies.
\end{abstract}

The updated model provides a new, high-resolution data set of the contemporary near-surface climate and SMB of the AIS; this model version will be used for future climate scenario projections in a forthcoming study.

\section{Introduction}

Before being able to accurately predict future changes in the climate and surface mass balance (SMB) of the Antarctic ice sheet (AIS), it is required that its contemporary climate and SMB are realistically modelled. The interaction of the ice sheet with its atmospheric environment can be studied with regional climate models (RCMs) that are specifically adapted for use over the polar ice sheets of Greenland (Noël et al., 2016; Langen et al., 2017; Fettweis et al., 2017) and Antarctica (Gallée et al., 2013; Van Wessem et al., 2014b). Such polar RCMs explicitly calculate the individual components of the ice sheet SMB, such as precipitation, snow sublimation and surface meltwater run-off into the ocean. Combining integrated SMB with estimates of glacial discharge $(D)$ then gives the mass balance of the ice sheet (MB) and its asso- 
ciated contribution to global sea level change (Rignot et al., 2011c; Shepherd et al., 2012).

Over Antarctica, precipitation is the dominating component of the SMB, contributing $91 \%$ to the total (the sum of the absolute fluxes) mass budget (Van Wessem et al., 2014b). Snowfall rates are expected to rise in the future as a result of the increased moisture-holding capacity of a warming atmosphere (Ligtenberg et al., 2013; Palerme et al., 2017), which potentially compensates (Barrand et al., 2013) or amplifies (Winkelmann et al., 2012) changes in glacial discharge rates.

Surface melt rates along the coastal margins of the ice sheet can be significant and are further amplified by local climate features (Lenaerts et al., 2016b), possibly leading to ice shelf hydrofracturing (Van den Broeke et al., 2005a; Scambos et al., 2009; Kuipers Munneke et al., 2014), and the acceleration of grounded glaciers and related sea level rise (Rignot, 2004).

Polar RCMs are required to model the above processes realistically, and, in this study, the regional atmospheric climate model (RACMO2) is used at $27 \mathrm{~km}$ spatial resolution to simulate the climate and SMB of Antarctica. RACMO2 is able to accurately simulate climate variables over Antarctica (Van Lipzig et al., 2002; Reijmer et al., 2005; Van de Berg et al., 2006; Lenaerts et al., 2012b). However, substantial challenges remain. For instance, RACMO2 systematically underestimates snowfall, and hence the SMB, over the East Antarctic plateau. This negative bias was first identified in Van de Berg et al. (2006) but persisted in subsequent model versions at $\sim 10 \%$ (Van Wessem et al., 2014b). In addition, biases in the net longwave radiation and sensible heat fluxes (Van Wessem et al., 2014a) resulted in biases in the energy available for melt (King et al., 2015) or in the surface energy budget (SEB), the sum of all energy fluxes at the surface. As a result, the previous model versions were systematically too cold over the ice sheet (Van den Broeke, 2008). In regions of melt, too little meltwater percolates into and refreezes in the snow column, resulting in too-low snow temperatures (Van den Broeke, 2008). Although this bias was substantially reduced, it still remains at $-1.3 \mathrm{~K}$ in the latest model version (Van Wessem et al., 2014a).

One of the main causes of these discrepancies is shortcomings in the cloud microphysics. Biases in SMB and SEB are caused by too-thin clouds simulated over the AIS, resulting in too little snowfall, too much downwelling shortwave radiation and too little downwelling longwave radiation (Van Wessem et al., 2014a; King et al., 2015). In addition, these biases are potentially related to an unrealistic fractionation of ice and water content in these clouds, which significantly affects the sensitivity of the (cloud) radiative fluxes to changes in cloud content (King et al., 2015).

Another model issue is the relatively coarse horizontal resolution of RACMO2. A high spatial resolution is important for resolving the impact of the topography on the atmospheric motion in detail, realistically simulating topographyrelated processes such as katabatic winds and orographically forced precipitation (Genthon and Krinner, 2001). Since Van de Berg et al. (2006) and Van Lipzig et al. (2002) the horizontal resolution has been refined from 55 to $27 \mathrm{~km}$ in Lenaerts et al. (2012b), and recently climate simulations at $5.5 \mathrm{~km}$ resolution have been performed, focusing on specific regions such as the Antarctic Peninsula (AP) (Van Wessem et al., 2016), Dronning Maud Land (Lenaerts et al., 2016a), the West Antarctic coast (Lenaerts et al., 2017a) and Adèlie Land (Lenaerts et al., 2012a). Limitations in the model topography also result from biases in the source data sets used for aggregation (Liu et al., 2001; Bamber et al., 2009). These data sets are typically based on observational data from remote sensing techniques such as airborne (DiMarzio et al., 2007) and satellite measurements (Rignot et al., 2008), but frequent improvements are applied to these data sets as well (Griggs and Bamber, 2009; Borsa et al., 2014).

Here, we discuss the effects of an update from RACMO2.3 version $\mathrm{p} 1$ to version $\mathrm{p} 2$, which addresses the model challenges presented above. To assess whether this update improves the modelled climate of the AIS in terms of SEB and SMB, we revisit several of the evaluations in previous studies. First, Sect. 2 discusses the model, the updates included and the observational data sets used for model evaluation. Section 3 presents the changes in terms of simulated SEB and SMB for the full ice sheet, as well as the evaluation by comparison with the observations. Section 4 presents the specific changes and evaluation for the $5.5 \mathrm{~km}$ model version applied to the AP. Section 5 then discusses remaining challenges and model limitations, followed by a summary and conclusions in Sect. 6. This paper is part of a tandem model evaluation over the Greenland (part 1) and Antarctic (this study) ice sheets.

\section{Model and observational data}

\subsection{The Regional Atmospheric Climate Model RACMO2}

In this study, we use the Regional Atmospheric Climate MOdel version 2.3 (RACMO2.3). The model combines the atmospheric dynamics of the High Resolution Limited Area Model (HIRLAM, Undén et al., 2002) and the physics package CY33r1 of the European Centre for Medium-Range Weather Forecast (ECMWF) Integrated Forecast System (IFS) (ECMWF-IFS, 2008). The model assumes hydrostatic equilibrium and we have verified that at both horizontal resolutions (27 and $5.5 \mathrm{~km}$ ) the hydrostatic assumption provides realistic results (Van Wessem et al., 2015, 2016).

This version of the model is specifically applied to the polar regions by interactively coupling it to a multilayer snow model that calculates melt, refreezing, percolation and run-off of meltwater (Greuell and Konzelmann, 1994; Ettema et al., 2010). In addition, snow albedo is calculated through a prognostic scheme for snow grain size (Kuipers 
Munneke et al., 2011) while a drifting snow scheme simulates the interaction of the near-surface air with drifting snow (Déry and Yau, 1999; Lenaerts et al., 2010). Throughout this study, two model domains are addressed: RACMO2.3/ANT simulates the climate of the full Antarctic ice sheet (AIS), while RACMO2.3/AP is applied to the AP region specifically (Fig. 1).

\subsection{Surface energy budget and surface mass balance}

RACMO2.3 explicitly resolves surface melt by solving the surface energy budget (SEB; $\mathrm{W} \mathrm{m}^{-2}$ ), defined as

$$
M=\mathrm{SW}_{\mathrm{d}}+\mathrm{SW}_{\mathrm{u}}+\mathrm{LW}_{\mathrm{d}}+\mathrm{LW}_{\mathrm{u}}+\mathrm{SHF}+\mathrm{LHF}+G_{\mathrm{s}},
$$

where fluxes directed towards the surface are defined positive, $M$ is melt energy, SW and LW are the (upward- and downward) shortwave and longwave radiative fluxes, SHF and LHF are the sensible and latent turbulent heat fluxes and $G_{\mathrm{S}}$ is the subsurface conductive heat flux. Excess energy at the surface is used to produce meltwater which can percolate through the snow column, where it is refrozen or retained. Ultimately, when the snowpack is saturated, the meltwater runs off to the ocean, representing a negative component in the surface mass balance (SMB) of the ice sheet. The SMB, in $\mathrm{mm}$ w.e. $\mathrm{y}^{-1}$, is defined as

$\mathrm{SMB}=P_{\mathrm{tot}}-\mathrm{SU}_{\mathrm{s}}-\mathrm{SU}_{\mathrm{ds}}-\mathrm{ER}_{\mathrm{ds}}-\mathrm{RU}$,

where $P_{\text {tot }}$ represents total precipitation (snowfall, SN, plus rain, RA), SU surface $\left(\mathrm{SU}_{\mathrm{s}}\right)$ plus drifting snow $\left(\mathrm{SU}_{\mathrm{ds}}\right)$ sublimation, $\mathrm{ER}_{\mathrm{ds}}$ drifting snow erosion and RU meltwater runoff, the amount of liquid water (melt and rain) that is not retained or refrozen (RF) in the snowpack. Note that by defining SMB in this way, we include processes in the snowpack such as refreezing; this is formally referred to as the climatic SMB (Cogley et al., 2011).

\subsection{Model updates}

The model update includes small bug fixes and tuning of atmosphere and snow parameterisations, as summarised below. Special effort is made to synchronise the model updates to the Greenland and Antarctica model versions. Most of the updates presented below are therefore also implemented for Greenland, unless noted otherwise. Throughout this paper we will refer to the new RACMO2.3 version as RACMO2.3p2 and to the old version as RACMO2.3p1, where $\mathrm{p}$ stands for polar.

a. Previous studies found that the previous model version systematically underestimates snowfall and downwelling longwave radiation in the interior of the ice sheets of both Greenland (Noël et al., 2015) and Antarctica (Van Wessem et al., 2014b). Therefore, the critical cloud water and cloud ice content $\left(l_{\text {crit }}\right)$ threshold, which governs the onset of effective precipitation formation

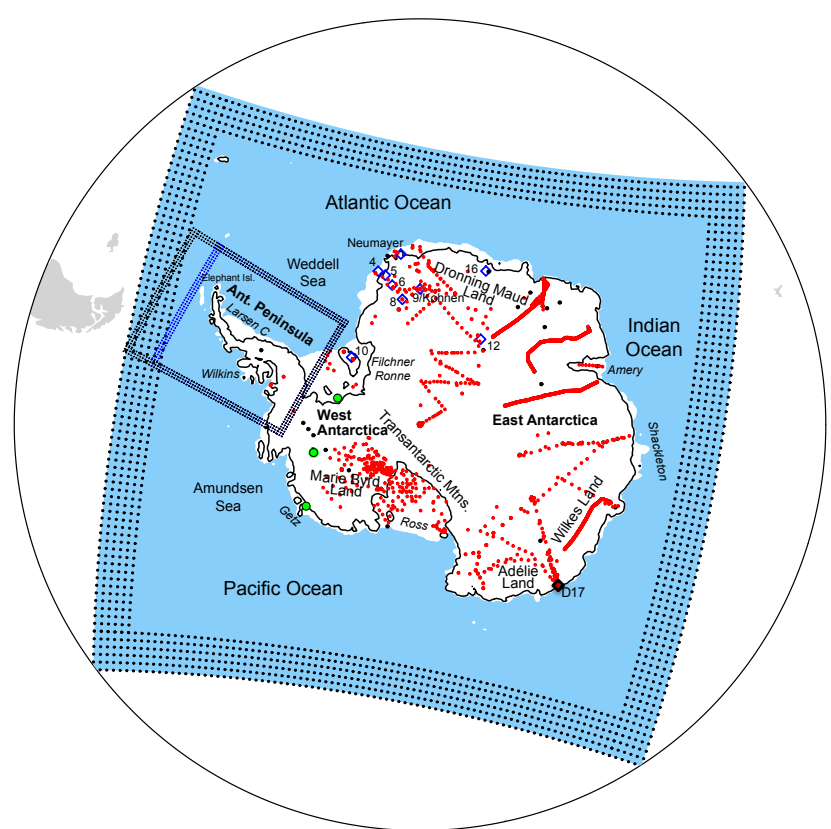

Figure 1. Map of Antarctica showing the in situ SMB observations (red dots), AWSs (blue diamonds), drifting snow measurement location D17 (black diamond), three snow radar regions (green dots) and $6410 \mathrm{~m}$ snow temperature observations (black dots) used in this study. Shown are the relaxation zones for both RACMO2.3p2/ANT and RACMO2.3p2/AP with the black dotted rectangles, as well as the RACMO2.3p1/AP domain (blue rectangle for the non-overlapping boundary). Also shown are the grounding line in black and relevant locations used throughout the text (with ice shelves in italics).

for mixed-phase and ice clouds, is increased in the following equation (adapted from ECMWF-IFS, 2008):

$G_{\text {precip }}=A c_{0} l_{\text {cld }}\left[1-\exp \left\{-\left(\frac{l_{\text {cld }}}{l_{\text {crit }} / \mathrm{BF}_{\mathrm{e}}}\right)^{2}\right\}\right]$.

Here, $A$ is a scaling value which is the cloud fraction for stratiform clouds and the updraught strength for convective clouds; $c_{0}$ is the coefficient for autoconversion of cloud ice/water into snow/rain; $l_{\text {cld }}$ is the total cloud ice and water content and $\mathrm{BF}_{\mathrm{e}}$ an enhancement factor for stratiform mixed phase clouds (ECMWF-IFS, 2008). The value of $l_{\text {crit }}$ is increased by a factor 2 for convective clouds and stratiform water/mixed phase clouds and by a factor 5 for stratiform ice clouds. This increase leads to both ice and water clouds lasting longer in the atmosphere before precipitating and therefore being advected further towards the ice sheet interior. As a result, we expect increased cloud cover for colder conditions and higher elevations and precipitation simulated further inland. Consequently, we expect to further decrease SEB and SMB biases in the AIS interior, in a way similar to Van Wessem et al. (2014a) and Van Wessem et al. (2014b). 
The values of $l_{\text {crit }}$ adopted in RACMO2 were obtained after conducting a series of sensitivity experiments, i.e. 1-year simulations, over Greenland to test the dependence of precipitation formation efficiency, spatial distribution and cloud moisture content on $l_{\text {crit }}$ and other cloud-tuning parameters. From these experiments, we found a linear relationship between $l_{\text {crit }}$ for mixed and ice clouds, which is the vertical integrated cloud content. These new settings were then tested over Greenland and Antarctica for a longer period and proved to raise the accumulation and downwelling radiation fluxes in the interior ice sheets of Greenland (Noël et al., 2018) and Antarctica (see Sects. 3.1, 3.2 and 3.4.3). The new value of $l_{\text {crit }}$ remains well within the range of values previously presented in the literature (Lin et al., 1983).

b. The linear saltation snow load parameter (Eq. 24, Déry and Yau, 1999) used in the drifting snow sublimation scheme is halved, i.e. from 0.385 to 0.190 (Lenaerts et al., 2012b), effectively halving the horizontal drifting snow mass and sublimation fluxes, without changing the length or frequency of drifting snow events, which were well simulated (Lenaerts et al., 2012b). This makes the simulated drifting snow fluxes more in line with the limited drifting snow observations over Greenland (Lenaerts et al., 2014), and we include it for the Antarctic simulations as well.

c. The albedo of superimposed ice layers now follows Kuipers Munneke et al. (2011). Previously, the albedo used for superimposed ice was prescribed at 0.55 , underestimating surface albedo and overestimating melt. Although the effect of this update is likely minor for Antarctica, where melting and the formation of superimposed ice layers in the current climate are rather limited in occurrence, it can result in better modelled surface albedo and melt locally and in future simulations.

d. A number of minor model bugs, mostly related to the snow model and the resulting snowmelt fluxes, were fixed. Improvements were made in the snow grain evolution scheme, leading to faster snow grain metamorphism in the uppermost snow layer. As a result, albedo decay is enhanced, which in turn enhances snowmelt. Two changes applied to the RACMO2 version used over Greenland have not been included in RACMO2/ANT: (1) the size of refrozen snow grains is reduced from 2 to $1 \mathrm{~mm}$ (this value was already used in RACMO2/ANT), and (2) the model soot concentration, consisting of dust and black carbon impurities deposited on snow, has been halved from 0.1 to $0.05 \mathrm{ppmv}$. Over Antarctica, likely no soot is present and model soot content is kept at zero.

\subsection{Initialisation and set-up}

RACMO2.3 uses a vertical mesh of 40 hybrid model layers and a horizontal resolution of $27 \mathrm{~km}$ over the AIS and of $5.5 \mathrm{~km}$ over the AP. Both model versions are forced at the lateral boundaries (Fig. 1) by ERA-Interim reanalysis data every 6h (January 1979-December 2016, Dee et al., 2011). RACMO2.3 is not coupled to an ocean model, and sea surface temperature and sea ice cover are prescribed from the reanalysis. The lateral boundaries are now taken from higher resolution $\left(0.75^{\circ}\right)$ ERA-Interim fields than before $\left(1.5^{\circ}\right)$, mostly affecting sea ice near the ice sheet margin.

RACMO2.3 is coupled to a snow model, a single column time-dependent model that describes the evolution of the firn layer based on a firn densification model (IMAU-FDM). It calculates firn density, temperature and liquid water content evolution based on forcing at the surface by surface temperature, accumulation and wind speed. Surface meltwater percolates into the model firn layer, where it can refreeze, be stored or percolate further down. The retention of meltwater is based on the tipping-bucket method (i.e. liquid water is stored in the first available layer and transported downwards only when it exceeds the maximum capillary retention). Liquid water that reaches the bottom of the firn layer is removed as run-off. More details on the snow model can be found in Ettema et al. (2010), Ligtenberg et al. (2011) and Kuipers Munneke et al. (2015).

Both RACMO2.3/ANT and RACMO2.3/AP are initialised on 1 January 1979; the initial firn pack is taken from a simulation with an offline IMAU-FDM (Ligtenberg et al., 2011), which has the same physics but a higher vertical resolution than the internal snow model and is driven by the previous RACMO2.3 climatologies for both model versions (Van Wessem et al., 2014b, 2016).

\subsubsection{Specific RACMO2.3p2/ANT set-up changes}

a. The model topography in earlier model versions was aggregated from the digital elevation model (DEM) from Liu et al. (2001). The updated topography is based on the (1 km spatial resolution) DEM from Bamber et al. (2009), which is derived from a combination of satellite radar and laser data. As a result, the topography in the coastal regions is now better resolved (Griggs and Bamber, 2009), likely resulting in better modelled topography-related variables, such as melt, katabatic winds and orographic precipitation.

b. To better simulate SMB interannual variability in RACMO2.3p2, upper-atmosphere relaxation (UAR or nudging) of temperature and wind fields is applied every $6 \mathrm{~h}$ for the model atmospheric levels above $600 \mathrm{hPa}$ (Van de Berg and Medley, 2016). UAR is not applied to atmospheric humidity fields in order not to alter clouds and precipitation formation in RACMO2. Additional details 
Table 1. The AWS topographic characteristics and period of operation (until December 2011). No. months represents the number of available months over the total months (725/770) of the model period (January 1979-December 2011). If no end time is indicated, the AWS is still operational at the end of 2011. For Neumayer station only cumulative melt is used in this study (Sect. 3.5.5.). Obs is observed; mod is modelled.

\begin{tabular}{|c|c|c|c|c|c|c|c|c|c|c|}
\hline AWS & 4 & 5 & 6 & 8 & 9 & 10 & 11 & 12 & 16 & Neumayer \\
\hline Latitude & $72^{\circ} 45^{\prime} \mathrm{S}$ & $73^{\circ} 06^{\prime} \mathrm{S}$ & $74^{\circ} 28^{\prime} \mathrm{S}$ & $76^{\circ} 00^{\prime} \mathrm{S}$ & $75^{\circ} 00^{\prime} \mathrm{S}$ & $79^{\circ} 34^{\prime} \mathrm{S}$ & $71^{\circ} 09^{\prime} \mathrm{S}$ & $78^{\circ} 39^{\prime} \mathrm{S}$ & $71^{\circ} 57^{\prime} \mathrm{S}$ & $70^{\circ} 39^{\prime} \mathrm{S}$ \\
\hline Longitude & $15^{\circ} 29.9^{\prime} \mathrm{W}$ & $13^{\circ} 09.9^{\prime} \mathrm{W}$ & $11^{\circ} 31.0^{\prime} \mathrm{W}$ & $08^{\circ} 03^{\prime} \mathrm{W}$ & $00^{\circ} 00^{\prime} \mathrm{E} / \mathrm{W}$ & $45^{\circ} 47^{\prime} \mathrm{W}$ & $06^{\circ} 42^{\prime} \mathrm{W}$ & $35^{\circ} 38^{\prime} \mathrm{E}$ & $23^{\circ} 20^{\prime} \mathrm{E}$ & $8^{\circ} 15^{\prime} \mathrm{W}$ \\
\hline Elevation (obs) & $34 \mathrm{~m}$ & $363 \mathrm{~m}$ & $1160 \mathrm{~m}$ & $2400 \mathrm{~m}$ & $2892 \mathrm{~m}$ & $890 \mathrm{~m}$ & $700 \mathrm{~m}$ & $3620 \mathrm{~m}$ & $1300 \mathrm{~m}$ & $40 \mathrm{~m}$ \\
\hline Elevation (mod) & $23 \mathrm{~m}$ & $332 \mathrm{~m}$ & $1219 \mathrm{~m}$ & $2405 \mathrm{~m}$ & $2856 \mathrm{~m}$ & $789 \mathrm{~m}$ & $224 \mathrm{~m}$ & $3621 \mathrm{~m}$ & $1130 \mathrm{~m}$ & 55 \\
\hline Start & Dec 1997 & Feb 1998 & Jan 1998 & Jan 1998 & Dec 1997 & Jan 2001 & Jan 2007 & Dec 2007 & Feb 2009 & Jan 1992 \\
\hline End & Dec 2002 & - & Jan 2009 & Jan 2003 & - & Jan 2006 & - & - & - & Dec 2015 \\
\hline No. months & $60 / 60$ & $167 / 167$ & $134 / 134$ & $19 / 44$ & $162 / 168$ & $48 / 54$ & $57 / 59$ & $49 / 49$ & $29 / 35$ & \\
\hline
\end{tabular}

about the implementation and the effects of upper-air relaxation are found in Van de Berg and Medley (2016).

\subsubsection{Specific RACMO2.3p2/AP set-up changes}

a. The DEM used in RACMO2.3/ANT was already used for the region south of $70^{\circ} \mathrm{S}$ (Van Wessem et al., 2016). This topography remains unchanged in the new model version. However, a projection parameter incorrectly used in the previous simulations has been changed, slightly altering the aggregation of the DEM to the model topography, resulting in a northward $(\sim 5 \mathrm{~km}$; one grid box) displacement of topographic features.

b. The model integration domain is extended by 60 grid points to the north of the original RACMO2.3/AP domain, allowing the inclusion of the South Shetland Islands and Elephant Island well into the domain (see Fig. 1).

c. Upper-air relaxation in RACMO2.3/AP is not used, as the model domain is smaller therefore better constrained at the lateral boundaries, and because the wind relaxation would smooth out orographic precipitation over the detailed AP topography.

\subsection{Observational data}

We evaluate the updated model by revisiting the comparisons of modelled SMB components and SEB in previous studies (Van Wessem et al., 2014a, b, 2015, 2016). These observational data include SEB data from automatic weather stations (AWSs), $10 \mathrm{~m}$ snow temperature, in situ SMB observations, accumulation radar profiles and solid ice discharge estimates. Detailed descriptions of these methods are provided in their respective papers. Here, we describe updates to the observational data sets only.

\subsubsection{Automatic weather stations}

We evaluate modelled near-surface wind, temperature and SEB components using nine AWSs located in Dronning Maud Land (DML) in different climate regimes. These
AWSs measure all four radiation components as well as humidity and snow temperature, which are used to force an energy balance model (EBM), effectively closing the SEB at AWS locations. A summary of the location and data records of the AWSs is provided in Table 1 and locations are shown in Fig. 1. We use the same time period (1979-2011) for evaluation as in Van Wessem et al. (2014a) and did not extend the few AWSs that have longer records. For more details on the EBM see Van den Broeke et al. (2005a, b) and Reijmer and Oerlemans (2002). All data from AWSs are monthly averaged and compared with data from the same months from RACMO2.3.

In addition to these AWSs, in order to evaluate the modelled melt fluxes, we have included SEB data from Neumayer station in DML that span a longer time period (1990-2015) (Van den Broeke et al., 2009). We use these data to force the EBM and test the sensitivity of the calculated melt to two different surface roughness lengths: $z_{0}=28$ (a commonly used setting) $\mathrm{mm}$ and $z_{0}=1 \mathrm{~mm}$ (standard setting in the EBM).

\subsubsection{In situ SMB and temperature observations}

We compare the updated RACMO2.3/ANT modelled SMB with 3234 in situ SMB observations (Fig. 1) described by Favier et al. (2013). For modelled surface temperature $\left(T_{\mathrm{s}}\right)$ evaluation, we use the $6410 \mathrm{~m}$ snow temperature observations (Fig. 1) used in Van Wessem et al. (2014a), which at this depth are representative of annual average surface temperature.

\subsubsection{Accumulation radar}

In order to evaluate model performance in capturing the temporal variability in SMB, we use radar-derived annual accumulation rates from 1980 to 2009 over much of the Thwaites glacier catchment area generated by Medley et al. (2013). The accumulation rates were derived from the Center for Remote Sensing of Ice Sheets snow radar system as part of NASA Operation IceBridge (Leuschen, 2014). Similarly, we calculate accumulation rates using snow radar data from two additional surveys (Fig. 1): the western Getz ice shelf (17 October 2011) and the Ronne ice shelf (15 Novem- 
ber 2015) near the Institute Ice Stream grounding zone. The areas covered by these new surveys are much smaller than the Thwaites glacier survey $(\sim 1600 \mathrm{~km})$ but are larger than the RACMO2.3 grid cell width (Getz: $\sim 75 \mathrm{~km}$, Ronne: $\sim 50 \mathrm{~km}$ ), averaging out much of the spatial variability. We use a method described in Medley et al. (2015) which allows for spatial variations in the firn density profile in both radar-depth estimation as well as conversion to water equivalence. The method iteratively solves for a depth-density profile for each measurement that is consistent with the radarderived accumulation rate as well as long-term modelled $2 \mathrm{~m}$ air temperature from MERRA-2 and an initial density of $350 \mathrm{~kg} \mathrm{~m}^{-3}$. For the Ronne ice shelf survey, we are able to generate a 30-year time series (1985-2014); however, we are only able to record 10 years of accumulation over the Getz ice shelf, which is due to its high accumulation rate $\left(\sim 900 \mathrm{~mm}\right.$ w.e. $\left.\mathrm{y}^{-1}\right)$. Thus, the model evaluation over the Getz is less robust than over the Ronne and Thwaites surveys.

\subsubsection{GRACE}

The Gravity Recovery and Climate Experiment (GRACE) mission provides monthly observations of mass changes across the AIS at a resolution of $\sim 300 \mathrm{~km}$. To assess temporal simulated SMB variability, we regionally compare cumulative SMB with the GRACE observations on a regional scale. The GRACE data (CSR RL05) are processed as in Van Wessem et al. (2014b). Mass anomalies are assigned to predefined drainage basins (Zwally et al., 2012). To better capture the higher SMB variability in the marginal zones, these basins are split up into coastal and interior sub-basins. The assigned anomalies are then converted to pseudo-GRACE observations and adjusted until the differences with the actual GRACE observations are minimised in a least-squares sense. GRACE measures the integral sum of mass anomalies along the satellite orbit. Atmospheric and oceanic mass variability is removed by the processing centres using numerical models. However, residual signals may remain due to model deficiencies, mostly at high frequencies. To reduce the aliasing effects of these signals, both the GRACE and RACMO2.3 data are smoothed with a 7-month moving average filter. As GRACE measures the sum of SMB and ice dynamics, which generally act at slower timescales, all time series are detrended and a quadratic acceleration term is removed.

\subsubsection{Drifting snow in Adélie Land}

Observations of horizontal drifting snow transport fluxes $\left(\mathrm{TR}_{\mathrm{ds}}\right)$ were performed in Adélie Land, East Antarctica (Fig. 1), where surface atmospheric conditions are well monitored at the permanent French Dumont d'Urville station (Favier et al., 2011). The coastal region is characterised by frequent strong katabatic winds that are regularly associated with aeolian snow transport events (Trouvilliez et al., 2014). The evaluation data set includes snowdrift acoustic measurements collected using second-generation FlowCapt ${ }^{\mathrm{TM}}$ devices during 2013 at a coastal location of Adélie Land, as described in Amory et al. (2017). The measurement system consists of two $1 \mathrm{~m}$ long tubes superimposed vertically to sample the first two metres above the snow surface, which largely represent the total snow mass flux (Mann et al., 2000). Monthly values of horizontal snowdrift transport from 0 to $2 \mathrm{~m}$ are computed from half-hourly estimates of the snow mass flux and are compared with snowdrift transport fluxes from the drifting snow routine of RACMO2.3. The measured flux represents a minimum estimate of the total column flux.

\subsubsection{QuikSCAT melt fluxes}

We use estimates of surface meltwater production from the satellite radar backscatter time series from QuikSCAT (QSCAT), which is calibrated with SEB-derived melt flux observations (Trusel et al., 2013). We compare these with modelled melt fluxes for the period 2000-2009 for the ice shelf regions denoted in Fig. 1.

\subsubsection{CloudSat-CALIPSO}

To evaluate the modelled downwelling radiative fluxes we use a modified version of release 04 (R04) of the CloudSat Level 2B Fluxes and Heating Rates (2B-FLXHR-LIDAR) product (Henderson et al., 2013) with specific adaptations for the polar atmosphere (Van Tricht et al., 2016b), combining cloud properties retrieved by CloudSat-CALIPSO (CC), reanalysis data from ERA-Interim and surface properties, which drives a broadband radiative transfer model. Data from 2007 to 2010 are available at a horizontal resolution of $2^{\circ} \times 1^{\circ}$ as described in Lenaerts et al. (2017b) and Matus and L'Ecuyer (2017). The performance of this product over polar regions has been evaluated by statistical comparison with AWS measurements both in the Arctic as well as in the Antarctic (Van Tricht et al., 2016a, b). Root mean square deviations (RMSDs) of the computed fluxes and the AWS measurements from the four Antarctic AWSs are used as uncertainties in the fluxes used in this study.

\subsubsection{Upper-air profiles}

To evaluate modelled (upper) atmospheric conditions we use radiosonde data from Kohnen Station, close to AWS 9, maintained by the Alfred Wegener Institute (AWI). As part of austral summer campaigns at Kohnen Station $\left(75^{\circ} \mathrm{S}, 0^{\circ} \mathrm{E}\right.$, $2892 \mathrm{~m}$ a.s.1.), in 2005/2006 and 2013/2014, radiosonde measurements were performed four times a day (00:00, 06:00, 12:00 and 18:00 UTC). Radiosondes of type RS92-SGP manufactured by Vaisala, Finland, were used. The sondes carried sensors to measure pressure, temperature and humidity and a GPS receiver to capture wind speed and wind direction. At 06:00 and 18:00 UTC a $200 \mathrm{~g}$ balloon was launched. 


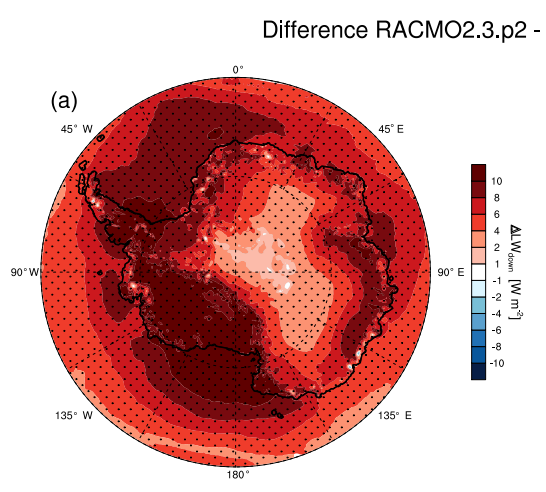

RACMO2.3p1 for 1979-2014
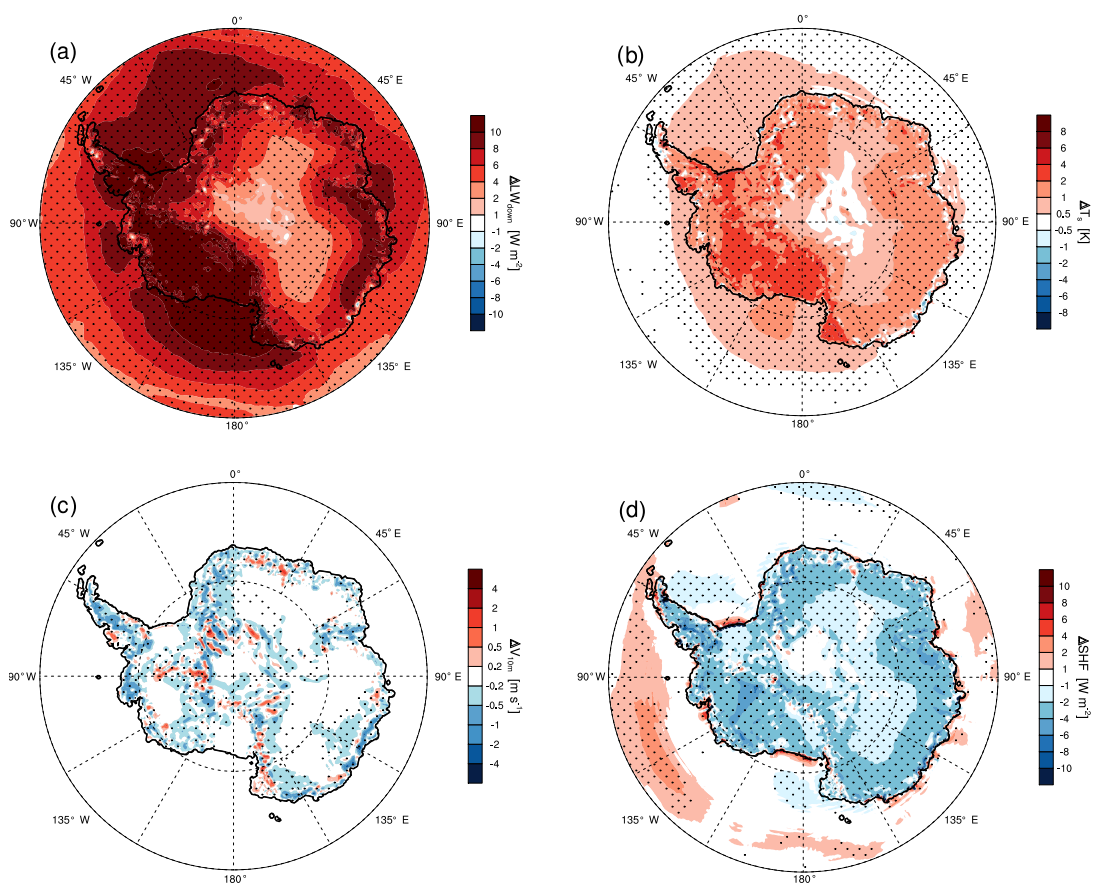

Figure 2. Annual average (1979-2014) difference (RACMO2.3p2-RACMO2.3p1) of (a) downwelling longwave radiation (LW d $_{\text {), }}(\mathbf{b})$ surface temperature $\left(T_{\mathrm{S}}\right),(\mathbf{c}) 10 \mathrm{~m}$ wind speed $\left(V_{10 \mathrm{~m}}\right)$ and $(\mathbf{d})$ sensible heat flux (SHF). Areas where the difference exceeds 1 standard deviation of the difference are stippled.

At 00:00 and 12:00 UTC a $600 \mathrm{~g}$ balloon was utilised, which reached altitudes up to $35 \mathrm{~km}$ above sea level. The radiosondes transmitted vertical data in time steps of $2 \mathrm{~s}$. Hence, we obtain profile data with a vertical resolution of about approximately $10 \mathrm{~m}$, which provide the basis for the evaluation of RACMO2.3/ANT data. Here, we use data from austral summer 2013/2014 which are presented in Sect. 3.4.4; results for 2005/2006 are similar.

\subsubsection{Discharge estimates}

To evaluate RACMO2.3/AP modelled SMB we use the solid ice discharge estimates from Wuite et al. (2015), as also used in Van Wessem et al. (2016). We added similar discharge estimates for the George VI ice shelf (Hogg et al., 2017).

\section{Results: full ice sheet at $27 \mathbf{~ k m}$}

\subsection{Changes in modelled SEB}

Figure 2 shows the difference in modelled annual mean (1979-2014) SEB and near-surface variables between RACMO2.3p2 and RACMO2.3p1. Figure 2a shows a relatively uniform increase in $\mathrm{LW}_{\mathrm{d}}$ of up to $10 \mathrm{~W} \mathrm{~m}^{-2}$, a result of the changes in the model cloud scheme, leading to more clouds inland. The increase is largest over the sea ice and along the coastal margins and the escarpment zone of the ice sheet, where cloud coverage peaks. Figure $2 b$ illustrates that surface temperature $T_{\mathrm{S}}$ increased uniformly as a result of the increase in $\mathrm{LW}_{\mathrm{d}}$. At the East Antarctic plateau changes are smaller. Differences in $V_{10 \mathrm{~m}}$ are small and most pronounced in regions of steep topography, where changes in the model surface topography are largest but are also due to changes in the near-surface temperature inversion $T_{\mathrm{inv}}=T_{\mathrm{s}}-T_{2 \mathrm{~m}}$ as a result of the changes in $T_{\mathrm{s}}$. Finally, Fig. $2 \mathrm{~d}$ shows the resulting changes in the sensible heat flux (SHF), which are closely related to the changes in $\mathrm{LW}_{\text {net }}$, causing SHF to drop as the surface temperature inversion is weaker. Figure 2 also shows sharp local changes over polynyas between the iceshelf edge and the sea ice. These differences are mostly related to changes in the ice mask, resulting from the updated surface topography but are also related to the higherresolution ocean and sea ice boundary forcing. The latter change caused sea ice to be better resolved along the coastal margins, with associated changes in the surface fluxes.

\subsection{Changes in modelled SMB}

Figure 3 shows the related changes in the SMB components. First, the patterns in the change in total precipitation (snowfall and rainfall, Fig. 3a) are comparable to the changes in $\mathrm{LW}_{\mathrm{d}}$ and $T_{\mathrm{s}}$ : there is a migration of precipitation from the ocean and coastal margin towards the interior of the ice sheet due to the updated cloud scheme. However, in 

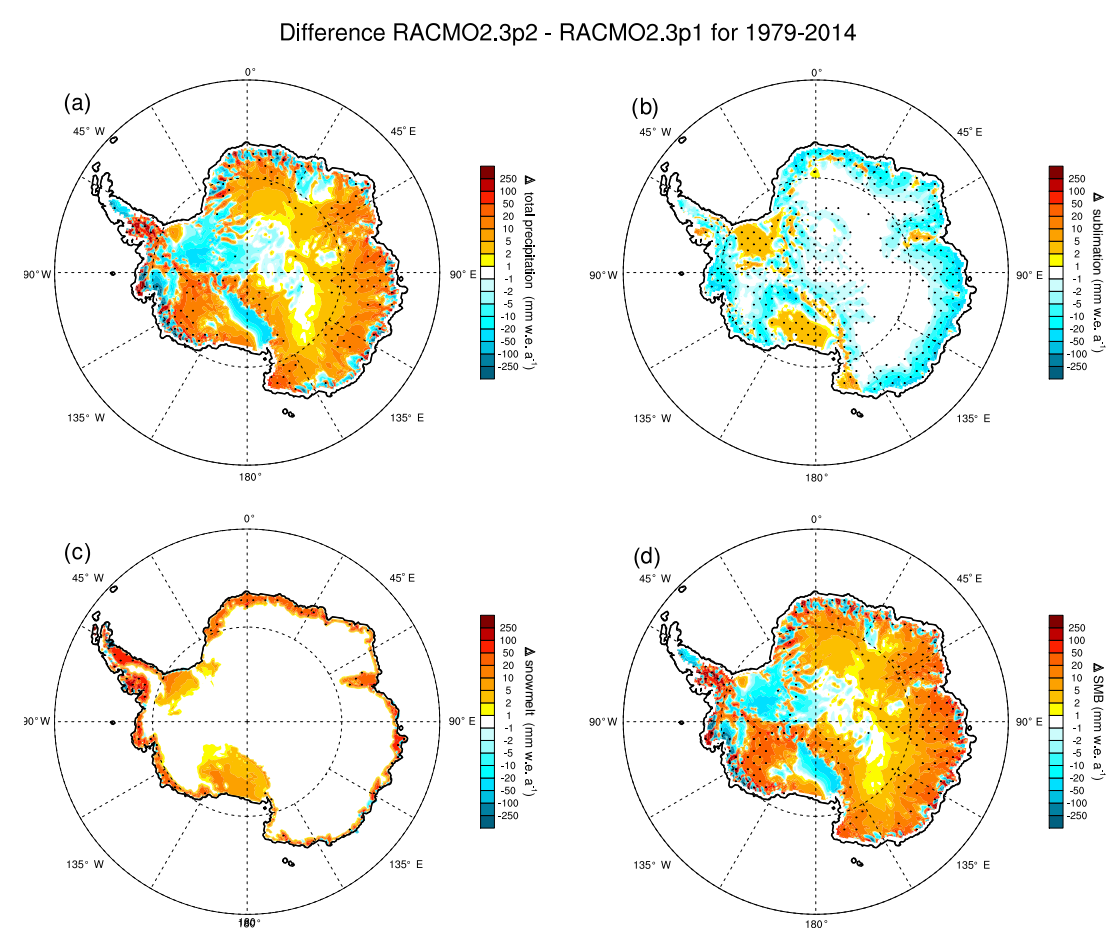

Figure 3. Annual average (1979-2014) difference (RACMO2.3p2-RACMO2.3p1) of (a) total precipitation (snow and rain), (b) total drifting snow and surface sublimation, (c) snowmelt and (d) SMB. Areas where the difference exceeds 1 standard deviation of the difference are stippled.

a few coastal regions with pronounced topography there is a decrease related to the updated model topography. For instance, enhanced precipitation shadow patterns are found in the Antarctic Peninsula (AP), parts of Dronning Maud Land (DML) and Marie Byrd Land (MBL). Figure 3b illustrates that sublimation fluxes are smaller locally, removing up to $200 \mathrm{~mm}$ w.e. $\mathrm{y}^{-1}$ less mass. This is a result of the lowered snow drift saltation parameter, causing drifting snow sublimation $\mathrm{SU}_{\mathrm{ds}}$ to be less efficient in the coastal and escarpment region where wind speeds and $\mathrm{SU}_{\mathrm{ds}}$ are the largest. Over the flat ice shelves, as well as some regions where the new topography has resulted in lower elevations, warmer conditions have resulted in a small increase in (surface) sublimation. Surface snowmelt fluxes (Fig. 3c) increased by $\sim 100 \mathrm{~mm}$ w.e. $\mathrm{y}^{-1}$ over the coastal region and ice shelves. The changes are mainly caused by the faster snow grain growth, which lowers surface albedo and enhances summer snowmelt. Surface melt has no influence on the SMB, as nearly all meltwater refreezes in the firn. Ultimately, changes in SMB (Fig. 3d) are dominated by changes in $P_{\text {tot }}$, which are the largest.

\subsection{Changes in integrated SMB}

Table 2 summarises the RACMO2.3 integrated values of the SMB components, calculated for the model ice mask including ice shelves, but excluding the
AP. In RACMO2.3p2/ANT, integrated SMB amounts to $2229 \mathrm{Gty}^{-1}$ with an interannual variability of $\sigma=109 \mathrm{Gty}^{-1}$, which is an increase of $69 \mathrm{Gty}^{-1}(3.2 \%)$. Changes in precipitation are mainly caused by a redistribution over the ice sheet; integrated changes over the total ice sheet are small: $P_{\text {tot }}$ increased slightly by $14 \mathrm{Gty}^{-1}(0.5 \%)$ to $2400 \pm 109 \mathrm{Gt}^{-1}$. The increase in SMB is mostly caused by a reduction in drifting snow sublimation $\mathrm{SU}_{\mathrm{ds}}$, which dropped by $79 \mathrm{Gty}^{-1}$, from $181 \pm 9$ to $102 \pm 5 \mathrm{Gty}^{-1}$. An increase of $22 \mathrm{Gty}^{-1}$ in surface sublimation partly compensates for this decrease and total SU decreased by 56 to $161 \pm 7 \mathrm{Gty}^{-1}$. Snowmelt increased significantly from $36 \pm 17$ to $71 \pm 28 \mathrm{Gt} \mathrm{y}^{-1}$, an increase of $97 \%$. The increase does not affect the SMB, as all extra meltwater (and rain) is modelled to refreeze in the snow $\left(71 \pm 28 \mathrm{Gty}^{-1}\right)$. The remaining SMB components (rainfall, $\mathrm{ER}_{\mathrm{ds}}$ and run-off) did not change significantly.

Integrated SMB for the grounded ice sheet (GIS), which is based on the Rignot et al. (2011a, b) drainage basin definitions excluding the AP, increased by 103 to $1885 \mathrm{Gty}^{-1}$, which is a bigger increase than when including the ice shelves. This difference is caused by a redistribution of snowfall towards the interior of the ice sheet (see Fig. 3a, d) and because changes in $\mathrm{SU}_{\mathrm{ds}}$ are mainly present over grounded ice (Fig. 3b). This effect is most profound over the East Antarctic ice sheet (EAIS), where the SMB increased by 

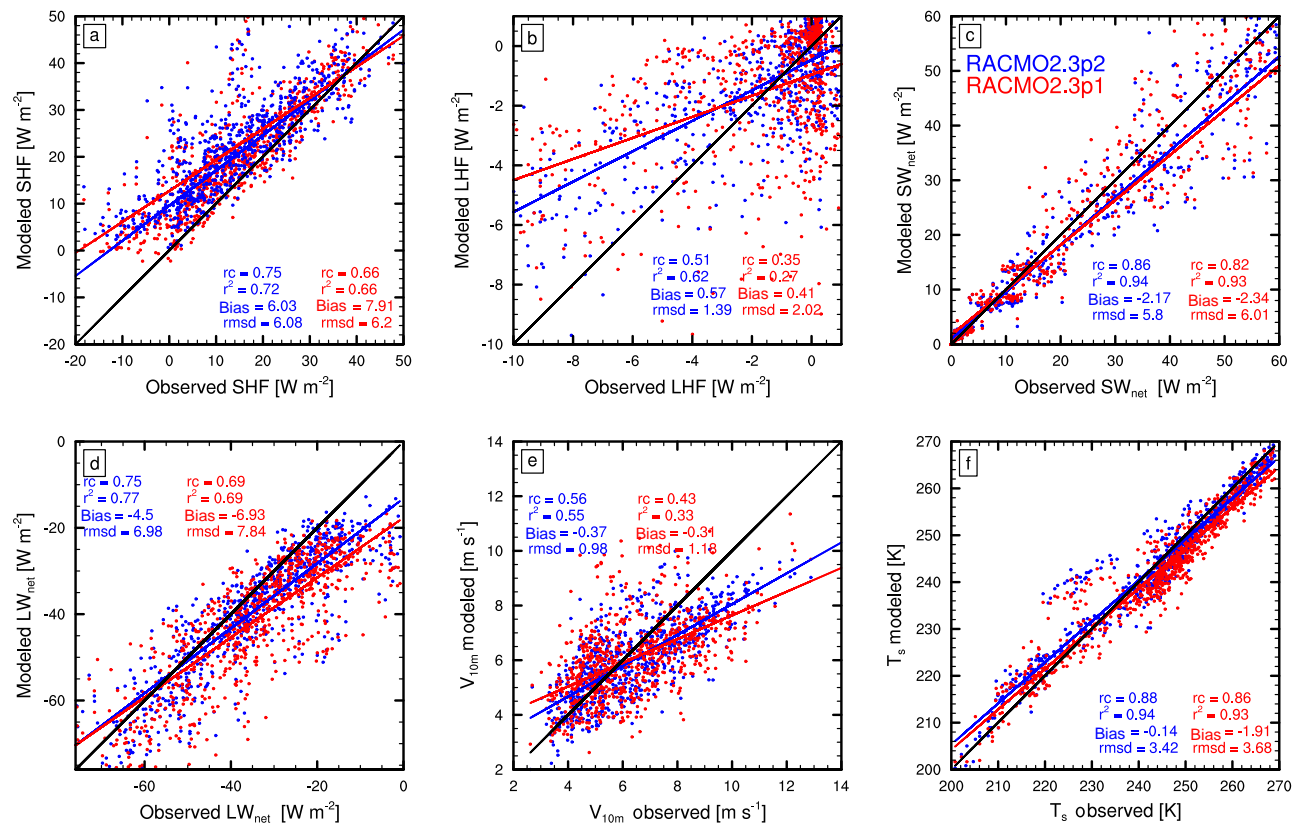

Figure 4. Correlation plots of RACMO2.3p2 (blue) and RACMO2.3p1 (red) as a function of the observation for monthly averages of the (a) sensible heat flux (SHF), (b) latent heat flux (LHF), (c) $\mathrm{SW}_{\text {net }}$, (d) $\mathrm{LW}_{\text {net }}$, (e) $V_{10 \mathrm{~m}}$ and (f) $T_{\mathrm{s}}$. Denoted for all variables are the slope Rc, determination coefficient $r^{2}$, bias and root mean square deviation (RMSD) for both model versions.

Table 2. Total ice sheet, including ice shelves and excluding the Antarctic Peninsula, integrated SMB mean 1979-2014 (the overlapping period for both model versions) values $\left[\mathrm{Gt}^{-1}\right]$ with interannual variability $\sigma$ : total (snow and rain) precipitation $\left(P_{\text {tot }}\right)$, snowfall (SN), rainfall (RA), total sublimation ( $\left.\mathrm{SU}_{\text {tot }}\right)$, surface sublimation $\left(\mathrm{SU}_{\mathrm{S}}\right)$, drifting snow sublimation $\left(\mathrm{SU}_{\mathrm{ds}}\right)$, drifting snow erosion $\left(\mathrm{ER}_{\mathrm{ds}}\right)$, run-off $(\mathrm{RU})$, snowmelt $(M)$ and refrozen mass $(\mathrm{RF})$. All values calculated on the RACMO2.3p2/ANT ice mask (Bamber et al., 2009). EAIS, WAIS and ISLANDS SMB are based on the Rignot et al., (2018) drainage basins and denote the grounded ice sheet. No values for RACMO2.3p1/ANT are given for the latter region; as they do not correspond with the RACMO2.3p1 ice mask used.

\begin{tabular}{|c|c|c|c|c|c|}
\hline & \multicolumn{2}{|c|}{ RACMO2.3p2 } & \multicolumn{2}{|c|}{ RACMO2.3p1 } & \multirow{2}{*}{$\begin{array}{l}\mathrm{p} 2-\mathrm{p} 1 \\
\text { mean }\end{array}$} \\
\hline & mean & $\sigma$ & mean & $\sigma$ & \\
\hline$P_{\text {tot }}$ & 2396 & 110 & 2386 & 118 & $+10(0.5 \%)$ \\
\hline SN & 2394 & 110 & 2383 & 109 & $+11(0.5 \%)$ \\
\hline RA & 3 & 1 & 2 & 1 & $1(50 \%)$ \\
\hline $\mathrm{SU}_{\text {tot }}$ & 161 & 7 & 217 & 11 & $-56(25 \%)$ \\
\hline $\mathrm{SU}_{\mathrm{s}}$ & 59 & 4 & 37 & 3 & $+22(60 \%)$ \\
\hline $\mathrm{SU}_{\mathrm{ds}}$ & 102 & 5 & 181 & 9 & $-79(43 \%)$ \\
\hline $\mathrm{ER}_{\mathrm{ds}}$ & 5 & 0.5 & 5 & 0.5 & 0 \\
\hline RU & 3 & 1 & 3 & 1 & 0 \\
\hline M & 71 & 28 & 36 & 17 & $+35(97 \%)$ \\
\hline RF & 71 & 28 & 36 & 17 & $+35(97 \%)$ \\
\hline SMB (TotIS) & 2229 & 109 & 2160 & 118 & $+69(3.2 \%)$ \\
\hline SMB (GIS) & 1885 & 95 & 1782 & 103 & $+103(5.8 \%)$ \\
\hline SMB (EAIS) & 1130 & 80 & 1051 & 94 & $+79(7.5 \%)$ \\
\hline SMB (WAIS) & 644 & 63 & 627 & 60 & $+17(2.7 \%)$ \\
\hline SMB (ISLANDS) & 110 & 11 & - & - & - \\
\hline
\end{tabular}

$79 \mathrm{Gty}^{-1}(7.5 \%)$, compared to an increase of only $17 \mathrm{Gt} \mathrm{y}^{-1}$ $(2.7 \%)$ over the West Antarctic ice sheet (WAIS).

\subsection{Evaluation of modelled SEB}

\subsubsection{Automatic weather stations}

Figure 4 compares monthly modelled SEB components with AWS observations. All components show consistent improvements. For net longwave radiation $\left(\mathrm{LW}_{\text {net }}\right)$, the determination coefficient $\left(r^{2}\right)$ increased from 0.69 to 0.77 , the bias decreased from -6.9 to $-4.5 \mathrm{~W} \mathrm{~m}^{-2}$ and the RMSD decreased from 7.8 to $7.0 \mathrm{~W} \mathrm{~m}^{-2}$. Similar but less pronounced improvements are found for the other components, most notably SHF. Improved correlation is mostly caused by the inclusion of upper-air relaxation in the model: temporal variability is now better constrained (Van de Berg and Medley, 2016). Improvements in bias and RMSD are mainly caused by changes in the cloud scheme.

Figure $4 \mathrm{e}$ shows small improvements for $V_{10 \mathrm{~m}}$. Temporal variability has improved in a similar way to the SEB, but improvements in slope, bias and RMSD are mostly unrelated to the improvements in the SEB components. These changes are related to the new model topography: the regression slope of $V_{10 \mathrm{~m}}$ went up considerably from 0.43 to 0.56 . This poor fit is generally caused by the relatively coarse horizontal resolution, resulting in an underestimation of surface slope in steep areas and an overestimation in flat areas (Reijmer and Oerlemans, 2002; Van Wessem et al., 2014a). Therefore, katabatic winds that are strongly related to the surface slope are too weak/strong in sloped/flat regions. Even though the horizontal resolution in RACMO2.3/ANT is unchanged, surface slope is likely better represented in the new model topogra- 

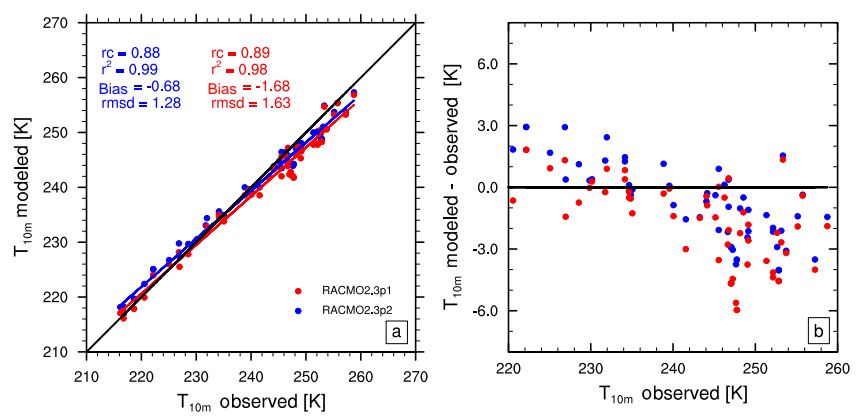

Figure 5. (a) RACMO2.3p2 (blue) and RACMO2.3p1 (red) and (b) modelled minus observed $10 \mathrm{~m}$ snow temperature as a function of the $10 \mathrm{~m}$ snow temperature observations. Denoted are the slope, determination coefficient $r^{2}$, bias and root mean square deviation (RMSD) for both model versions.

phy. The improvement in $T_{\mathrm{s}}$ (see below) also partly leads to a better representation of the surface temperature inversion $T_{\text {inv }}$, which affects the strength of the katabatic wind forcing.

Figure $4 \mathrm{f}$ shows modelled $T_{\mathrm{s}}$, as a function of observed $T_{\mathrm{s}}$ calculated by closing the SEB. A general shift to higher temperatures is seen for the entire temperature range, but temperature is still underestimated in most months. This warming results in better statistics overall, although at some locations temperature now is/remains overestimated. This overestimation overcompensates some of the biases, which is reflected in the change of the RMSD: while the absolute bias suggests a near-perfect match of modelled and observed $T_{\mathrm{S}}(-0.14 \mathrm{~K})$, RMSD shows a more modest improvement by $0.26 \mathrm{~K}$.

\subsection{2 $10 \mathrm{~m}$ firn temperature}

To evaluate changes in $T_{\mathrm{s}}$ over a larger area, Fig. 5 shows the comparison of RACMO2.3/ANT modelled $10 \mathrm{~m}$ firn temperature with 64 observations. Slope and spatial correlation remained similar, but the bias and RMSD decreased significantly, by 1 and $0.35 \mathrm{~K}$ respectively. The relatively small decrease in the RMSD is caused by the persistent positive temperature bias for the relatively cold East Antarctic plateau. At these locations the updated model now overestimates temperature by up to $3^{\circ}$, likely related to the slight overestimation of downwelling longwave radiation with the updated cloud scheme.

\subsubsection{CloudSat-CALIPSO}

Figure 6a shows the $\mathrm{LW}_{\mathrm{d}}$ and $\mathrm{SW}_{\mathrm{d}}$ bias and the observations (right axis) for all model ice sheet grid points averaged in nine surface elevation bins. For $\mathrm{SW}_{\mathrm{d}}$ the bias decreased by about $\sim 5 \mathrm{~W} \mathrm{~m}^{-2}$ for all elevation bins. Generally, over the AIS SW $\mathrm{d}_{\mathrm{d}}$ remains overestimated, but the new model version simulates these fluxes better. Improvements in $\mathrm{LW}_{\mathrm{d}}$ are also evident: here the old model version underestimated $\mathrm{LW}_{\mathrm{d}}$ for all elevation bins, but more so at lower elevations
$(<1500 \mathrm{~m})$. In the updated model the bias for these lower elevation bins, mostly representing the ice shelves and the WAIS, is reduced. However, for the elevation bins $>2000 \mathrm{~m}$, which represent the East Antarctic plateau, $\mathrm{LW}_{\mathrm{d}}$ is now overestimated by $\sim 4 \mathrm{~W} \mathrm{~m}^{-2}$. Overall, the downwelling radiative fluxes are likely better represented in the new model version, but errors in these fluxes are large. Only for intermediate elevations, the third to fifth bins, the changes appear larger than the uncertainty in the fluxes, which is based on a comparison with ground-based AWS observations (Van Tricht et al., 2016a).

Unfortunately, Fig. $6 \mathrm{~b}$ also shows that a systematic overestimation of both cloud ice and water is present in the new model version. Apparently, there is an error that compensates the biases in the downwelling radiative fluxes: by simulating clouds that are optically too thick, biases in the fluxes and also in $P_{\text {tot }}$ have decreased. The general biases in these cloud variables appear relatively large, especially for the coastal bins. However, the biggest fraction of grid points is located in the high-elevation bins as shown in the bar chart in Fig. 6a, where biases are the lowest.

\subsubsection{Kohnen Station radiosondes}

To assess upper-atmosphere conditions, Fig. 7 compares modelled temperature, relative humidity and wind speed profiles with radiosonde measurements conducted at Kohnen Station $\left(75^{\circ} \mathrm{S}, 0^{\circ} \mathrm{E}, 2892 \mathrm{~m}\right.$ a.s.l.). Here, we only show the average daily values for January 2014; the comparisons for other years give similar results. Figure 7 shows a consistent improvement in modelled temperature, relative humidity and wind speed. RMSD decreased significantly for all three variables and at all height levels in the atmosphere, a direct result of the upper-air relaxation included in RACMO2.3p2. The improvement is largest for wind speed; for temperature the changes are more variable near the surface $(0-1000 \mathrm{~m})$. It is interesting to see the significant improvement in simulated wind speed and temperature at the tropopause inversion $(\sim 8000 \mathrm{~m})$. Here, RMSD is largest, which is related to the maximum in wind speed and temperature at this level and the difficulty in simulating the accurate vertical location of the inversion.

\subsection{Evaluation of modelled SMB}

\subsubsection{In situ observations}

Figure 8 shows the SMB bias (model-observation) for both model versions averaged in nine surface elevation bins. The uniform increase in cloud cover and $P_{\text {tot }}$, accompanied by the decrease in drifting snow sublimation, increased SMB in all elevation bins. Only in the lowest bin, which represents the ice shelves, SMB decreased because precipitation now falls at higher elevations. The increase in SMB leads to a relative SMB bias that is generally below $5 \%$ for all bins above 

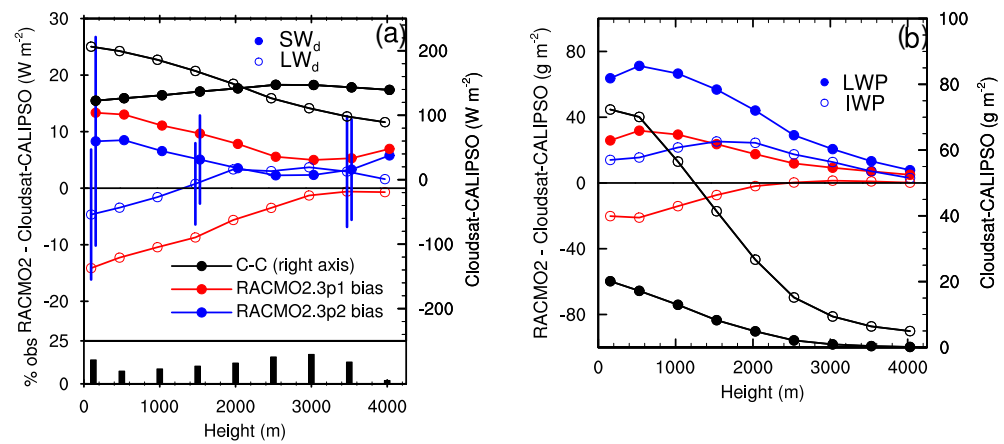

Figure 6. (a) Absolute bias (left axis) in average (2007-2010) modelled downwelling longwave radiation (LW ( $_{\text {) }}$ (open circles) and downwelling shortwave radiation $\left(\mathrm{SW}_{\mathrm{d}}\right)$ (closed circles) and (b) cloud ice water path (IWP) (open circles) and cloud liquid water path (LWP) (closed circles) for RACMO2.3p2 (blue) and RACMO2.3p1 (red) compared to the CloudSat-CALIPSO product (Van Tricht et al., 2016b). Also shown on (a) and (b) are the observational data (black circles, right axis). Error bars in (a) denote the root mean square difference (RMSD) from a statistical comparison of the CloudSat-CALIPSO fluxes and ground-based AWS observations (Van Tricht et al., 2016a), only shown for three bins as based on the elevations of the four ground-based AWSs used. The data are binned in $500 \mathrm{~m}$ surface elevation intervals $\left(0-250,250-750\right.$, etc.). The bar chart in (a) denotes the percentage of total grid points per elevation bin. To separate $\mathrm{LW}_{\mathrm{d}}$ and $\mathrm{SW}_{\mathrm{d}}$ fluxes, $x$ axis locations of each bin in (a) are displaced by $60 \mathrm{~m}$.

$250 \mathrm{~m}$ elevation. For some bins, SMB is even slightly overestimated. This change is consistent with those in temperature (Figs. $4 \mathrm{f}$ and $5 \mathrm{~b}$ ): more clouds in the interior result in higher temperatures and snowfall rates. The fifth and sixth elevation bins (1750-2750 m) show the largest improvements: negative biases decreased from -9 and $-16 \%$ to 1 and $-6 \%$. In these bins the improvements are larger than the uncertainty margins and therefore significant. In the coastal and escarpment zone of mainly West Antarctica (the 250-1750 bins), a small overestimation of SMB is now suggested, but the bias is not significantly different from zero.

\subsubsection{Snow accumulation radar}

Table 3 compares simulated annual SMB with annual accumulation rates derived from the snow radar in three regions in West Antarctica (Fig. 1). This comparison includes two new but small (unpublished) surveys over Getz and Ronne ice shelves. Correlations for annual values between the measured and simulated SMB have significantly improved for the three surveys, clearly resulting from the better-constrained interannual variability (Van de Berg and Medley, 2016). For the largest of the survey areas, Thwaites glacier, correlation $r$ has improved from 0.68 to 0.90 , comparable to the reanalyses in this region. Modelled mean accumulation rates over Thwaites remain slightly underestimated, but changes are small.

For the ice shelf comparisons correlation $(r)$ increased significantly from $\sim 0.5$ to $\sim 0.8$. These values are lower than the Thwaites comparison because (1) the accumulation rate over the Ronne ice shelf survey is lower $\left(\sim 190 \mathrm{~mm}\right.$ w.e. $\left.\mathrm{y}^{-1}\right)$, resulting in a lower signal-to-noise ratio in the radar time series, and (2) the Getz record is shorter.
Table 3. Comparison of RACMO2.3p2 and RACMO2.3p1 SMB $\left(\mathrm{mm} w . e . \mathrm{y}^{-1}\right.$ ) with radar-derived snow accumulation (Medley et al., 2013) for three regions in West Antarctica: Thwaites glacier (mean latitude/longitude: $\left.77.80^{\circ} \mathrm{S}, 104.66^{\circ} \mathrm{W}\right)$ and Getz $\left(74.51^{\circ} \mathrm{S}\right.$, $\left.125.54^{\circ} \mathrm{W}\right)$ and Ronne $\left(80.39^{\circ} \mathrm{S}, 72.21^{\circ} \mathrm{W}\right)$ ice shelves. Significant $(>95 \%)$ correlations are denoted in bold.

\begin{tabular}{lrrr}
\hline & Thwaites & Getz & Ronne \\
\hline Radar coverage & $\sim 1650 \mathrm{~km}$ & $\sim 75 \mathrm{~km}$ & $\sim 50 \mathrm{~km}$ \\
Snow radar SMB & 0.457 & 0.897 & 0.186 \\
RACMO2.3p1 SMB & 0.447 & 0.976 & 0.189 \\
RACMO2.3p2 SMB & 0.438 & 0.942 & 0.158 \\
\hline \multicolumn{4}{c}{ Correlation $(r)$ with radar } \\
\\
\hline RACMO2.3p1 & $\mathbf{0 . 6 8}$ & 0.49 & $\mathbf{0 . 5 1}$ \\
RACMO2.3p2 & $\mathbf{0 . 9 0}$ & $\mathbf{0 . 7 9}$ & $\mathbf{0 . 8 0}$ \\
\hline
\end{tabular}

\subsubsection{GRACE}

Figure 9 shows detrended and decelerated mass anomalies from GRACE, RACMO2.3p2 and RACMO2.3p1 for the West and East Antarctica ice sheets, the AP and for the AIS. Changes from RACMO2.3p1 to RACMO2.3p2 are small and likely insignificant as changes fall within the uncertainties of both products, but generally there is a slight improvement. For West Antarctica (Fig. 9a) and East Antarctica (Fig. 9c) the RMSD and correlation both improved slightly. For the AP changes are smaller and not significant. When these regions are combined, we find a slight improvement in the mass anomalies for the whole of the Antarctic ice sheet, but our main conclusion is that both model versions realistically simulate the Antarctic mass anomalies. 

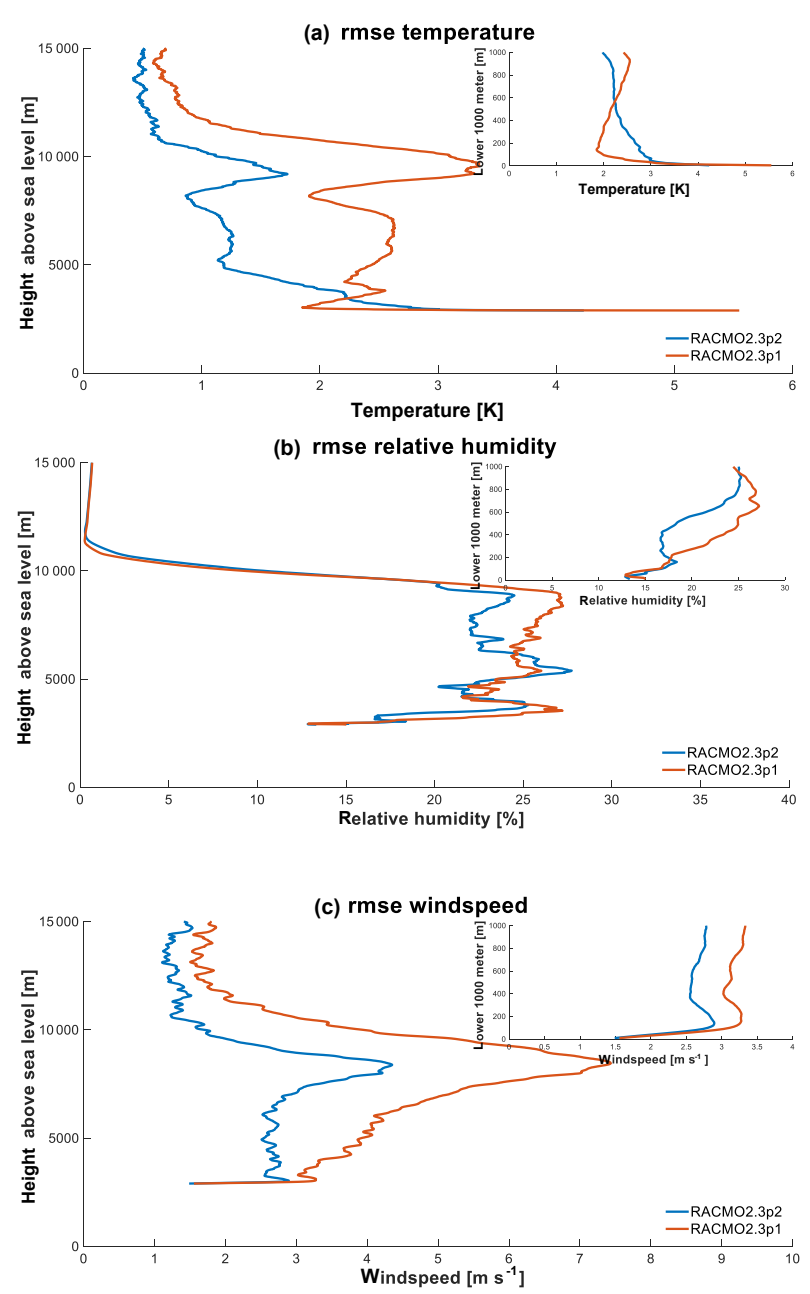

Figure 7. Root mean square error (RMSE) of average upperatmosphere temperature (a), relative humidity (b) and wind speed (c) from RACMO2.3p2 (blue) RACMO2.3p1 (red) and the radiosonde observations at Kohnen Station, from January 2014. Note that the lowermost level is at the surface of Kohnen Station, at $\sim 3000$ m elevation. Subpanels show a close-up of the lower $1000 \mathrm{~m}$.

\subsubsection{Drifting snow transport}

Figure 10a shows monthly cumulative horizontal drifting snow transport fluxes $\left(\mathrm{TR}_{\mathrm{ds}}\right)$ for 2013 from Amory et al. (2017), RACMO2.3p2 and RACMO2.3p1. Modelled TR $\mathrm{ds}_{\mathrm{s}}$ is computed for the full drifting snow layer, while the observed flux is measured for the first $2 \mathrm{~m}$ above the surface. Therefore, although the bulk of the flux is contained within the vicinity of the surface (Mann et al., 2000; Lenaerts et al., 2010), the observations represent a lower limit of $\mathrm{TR}_{\mathrm{ds}}$. Figure 10a illustrates a significant decrease in modelled $\mathrm{TR}_{\mathrm{ds}}$ for RACMO2.3p2, as a result of the lowered linear saltation snow load parameter (Déry and Yau, 1999). There is a good match, albeit an average underestimation by RACMO2.3p2
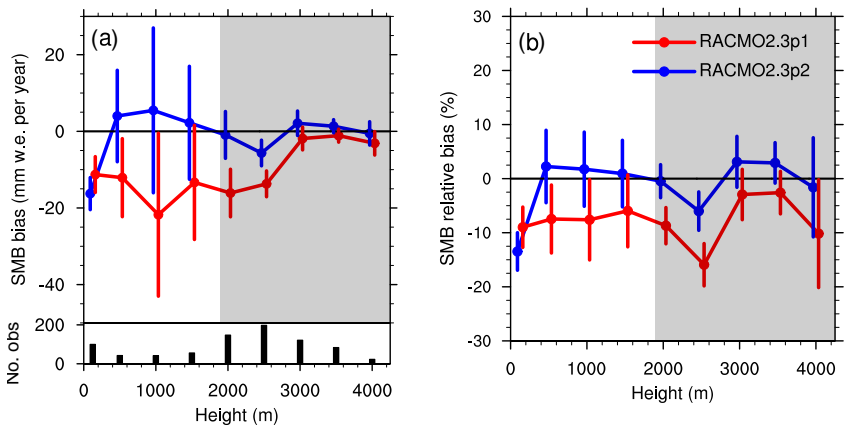

Figure 8. (a) Absolute bias and (b) relative bias ((model observation) $/$ model $\times 100 \%$ ) in modelled SMB for RACMO2.3p2 (blue) and RACMO2.3p1 (red). The data are binned in $500 \mathrm{~m}$ surface elevation intervals $(0-250,250-750$, etc.). Error bars denote the combined uncertainty of the model and observations within each height bin, based on Van de Berg et al. (2006) and Van Wessem et al. (2014a). Elevations above $2000 \mathrm{~m}$ (shaded grey) represent East Antarctica exclusively. The bar chart in (a) denotes the number of weighted observations in each bin. To separate blue and red lines, $x$ axis locations of each bin are displaced by $75 \mathrm{~m}$.

of 5.4 tons, with observed $\mathrm{TR}_{\mathrm{ds}}$. However, the underestimation of $\mathrm{TR}_{\mathrm{ds}}$ partly results from an underestimation of $V_{10 \mathrm{~m}}$ (Fig. 10b) by $\sim 2.3 \mathrm{~m} \mathrm{~s}^{-1}$ on average. Correcting for this bias in wind speed by linearly regressing modelled wind speed and $\mathrm{TR}_{\mathrm{ds}}$ reveals a likely improved match with the observations. Even though this is a simple first-order correction, it suggests that RACMO2.3p1 $\mathrm{TR}_{\mathrm{ds}}$ fluxes were too high.

\subsubsection{Surface melt}

To assess modelled surface melt fluxes, Fig. 11 correlates annual average (2000-2009) melt fluxes from RACMO2.3 and the QSCAT satellite for the whole AIS and six regions. The increase in snowmelt for the total AIS (inset) is evident and the negative bias decreased from -61 to $-15 \mathrm{Gt}^{-1}$, while the determination coefficient $r^{2}$ increased from 0.75 to 0.81 . For the six regions, melt is also better represented, although a few years remain in which melt is underestimated.

The largest underestimation is shown for Wilkins ice shelf. Here, observed melt fluxes may be overestimated due to extensive melt ponding and/or saturated firn conditions in this region (Trusel et al., 2013; Välisuo et al., 2014), a feature which negatively affects the QSCAT retrievals.

Figure 12 compares cumulative melt for 1990-2015 by RACMO2.3/ANT, and the melt calculated by an EBM (with two roughness length settings) forced with meteorological data from Neumayer station (Reijmer and Hock, 2008; König-Langlo, 2013). Updated model melt correlates best with the melt calculated by the EBM, but the total melt remains somewhat underestimated, consistent with the comparisons with QSCAT. The timing of the melt events is captured well: many of the strong melt summers, e.g. 1994/1995, 2000/2001 and 2013/2014, are now accurately modelled. 

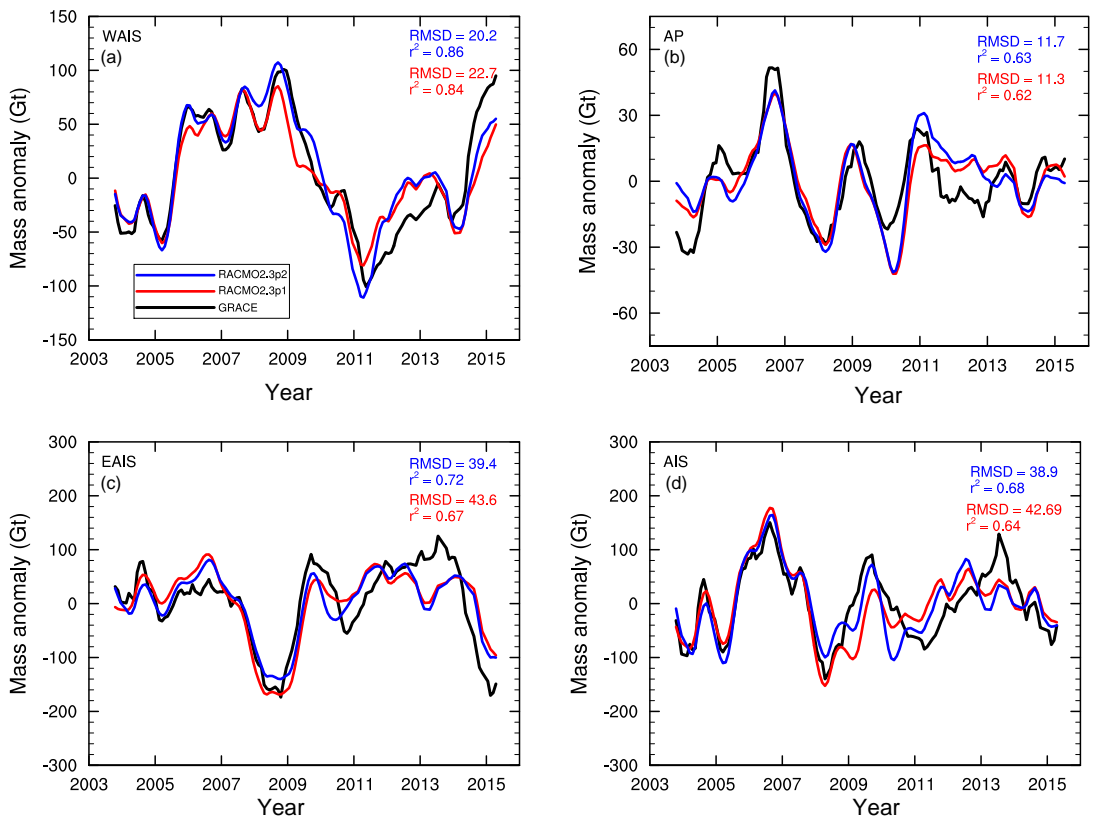

Figure 9. Detrended and decelerated average (for details see text) SMB anomalies of RACMO2.3p2 (blue), RACMO2.3p1(red) and GRACE (black) release RL05 for West Antarctica (a), the Antarctic Peninsula (b), East Antarctica (c) and the whole Antarctic ice sheet (AIS, d). Shown are root mean square deviation (RMSD) and correlation $\left(r^{2}\right)$.
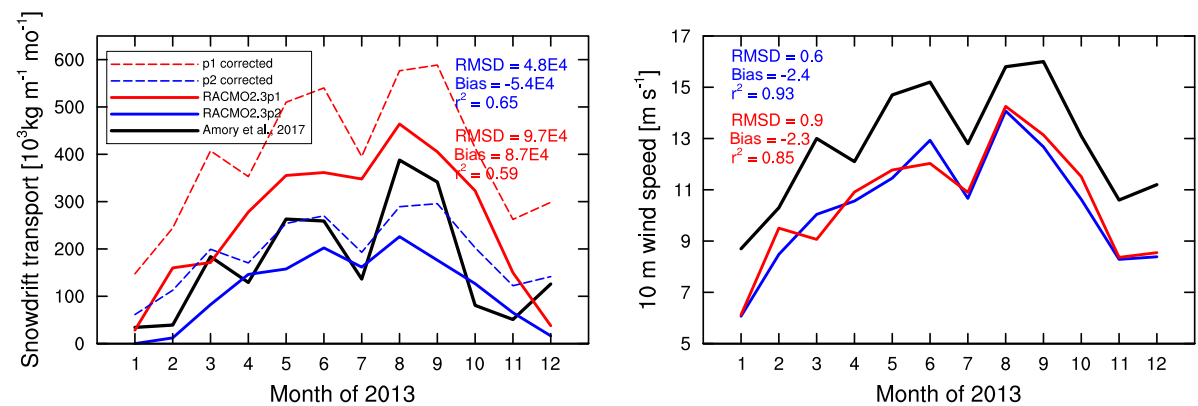

Figure 10. Monthly horizontal snow drift transport, $\mathrm{TR}_{\mathrm{ds}}\left(10^{3} \mathrm{~kg} \mathrm{~m}^{-1} \mathrm{month}^{-1}\right)(\mathbf{a})$, and $10 \mathrm{~m}$ wind speed, $V_{10 \mathrm{~m}}(\mathbf{b})$, from Amory et al. (2017), RACMO2.3p2 (blue) and RACMO2.3p1 (red) for the year 2013. The observed snow flux is calculated for the first $2 \mathrm{~m}$ only. The dashed lines represent the modelled transport fluxes corrected for the bias in $V_{10 \mathrm{~m}}$, using a first-order linear regression.

\section{Results: the Antarctic Peninsula at $5.5 \mathrm{~km}$}

\subsection{Changes in modelled SMB and SEB}

For RACMO2.3/AP at $5.5 \mathrm{~km}$ resolution, changes in SMB and SEB components are mostly consistent with those at a coarser resolution (Fig. 3). This means that for the AP we see an increase in $P_{\text {tot }}$ (Fig. 3a) and hence in the SMB (Fig. 3d) over the western slopes, a small decrease in $P_{\text {tot }}$ over the eastern ice shelves, a decrease in sublimation (Fig. 3b) and a considerable increase in snowmelt (Fig. 3d) where the RACMO2.3p2/ANT snowmelt is comparable to that simulated by RACMO2.3p2/AP (Fig. 11). There are only slight local differences in topography-related variables such as precipitation due to the different interpolation setting used to ag- gregate the model topography, shifting topographic features approximately one grid box northwards. However, as we will show in the next section, this hardly affects integrated SMB estimates.

Table 4 shows the integrated changes for RACMO2.3/AP. Total integrated SMB (1979-2014) increased by $16 \mathrm{Gt} \mathrm{y}^{-1}$ to $366 \pm 58 \mathrm{Gty}^{-1}$. This increase is mainly caused by changes in precipitation $\left(+14 \mathrm{Gty}^{-1}\right)$. Even though there are large local changes due to reprojection of the RACMO2.3/AP topography, it hardly affects the total integrated SMB. Changes in $\mathrm{SU}_{\mathrm{ds}}$ and the resulting $\mathrm{SU}$ are similar to those at a coarser resolution. While $\mathrm{SU}_{\mathrm{ds}}$ dropped by $4 \mathrm{Gt}^{-1}(44 \%), \mathrm{SU}_{\mathrm{s}}$ increased by $1 \mathrm{Gty}^{-1}$ and total sublimation SU now amounts to $8 \pm 2 \mathrm{Gty}^{-1}$, a decrease of $3 \mathrm{Gty}^{-1}$. Snowmelt increased significantly $\left(+10 \mathrm{Gt}^{-1}\right)$ but most of the meltwater increase 


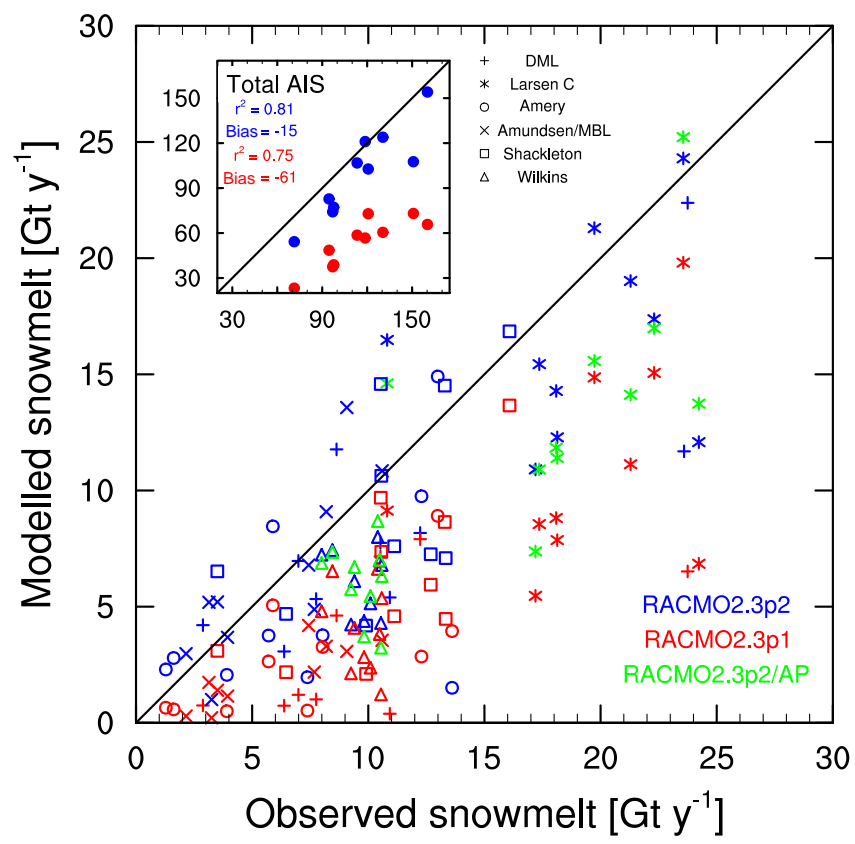

Figure 11. Modelled RACMO2.3p2 (blue), RACMO2.3p1 (red) and RACMO2.3p2/AP (green) as a function of observed QSCAT (Trusel et al., 2013) snowmelt in $\mathrm{Gt}^{-1}$. Shown are yearly 2000 2009 values for the total AIS (subpanel) and area-averaged values for six regions in Antarctica defined in Trusel et al. (2013): Dronning Maud Land (DML, plus signs), Larsen C ice shelf (asterisks), Amery Ice Shelf (open circles), Amundsen Sea embayment/Marie Byrd Land (crosses), Shackleton Ice Shelf (squares) and Wilkins Ice Shelf (triangles). Denoted are correlation $r^{2}$ and bias for the total AIS.

is refrozen in the snowpack $\left(+9 \mathrm{Gty}^{-1}\right)$. As a result runoff fluxes remain similar to the fluxes simulated in the old version. Relatively, most of the SMB increase comes from an increase in the eastern Antarctic Peninsula (EAP) SMB $(+5.3 \%)$, while the SMB in the western Antarctic Peninsula (WAP) increased by $3.9 \%$.

\subsection{Evaluation of modelled SMB}

Changes in RACMO2.3/AP are generally small and most changes are also visible at a coarser resolution, and only one previous evaluation with new observational data is revisited.

\subsubsection{Discharge estimates}

Figure 13 shows RACMO2.3/AP average SMB (1979-2016) as a function of glaciers draining in Larsen B (a, Wuite et al., 2015) and George VI ice shelves (b, Hogg et al., 2017) for $1995 / 1996$, when these were assumed to be in balance. Changes due to the model update are small yet different for the two regions. For Larsen B a consistent improvement in modelled SMB is seen: $r^{2}$, bias and RMSD all marginally improved. For George VI SMB values are an order of magnitude larger. The bias improved for the

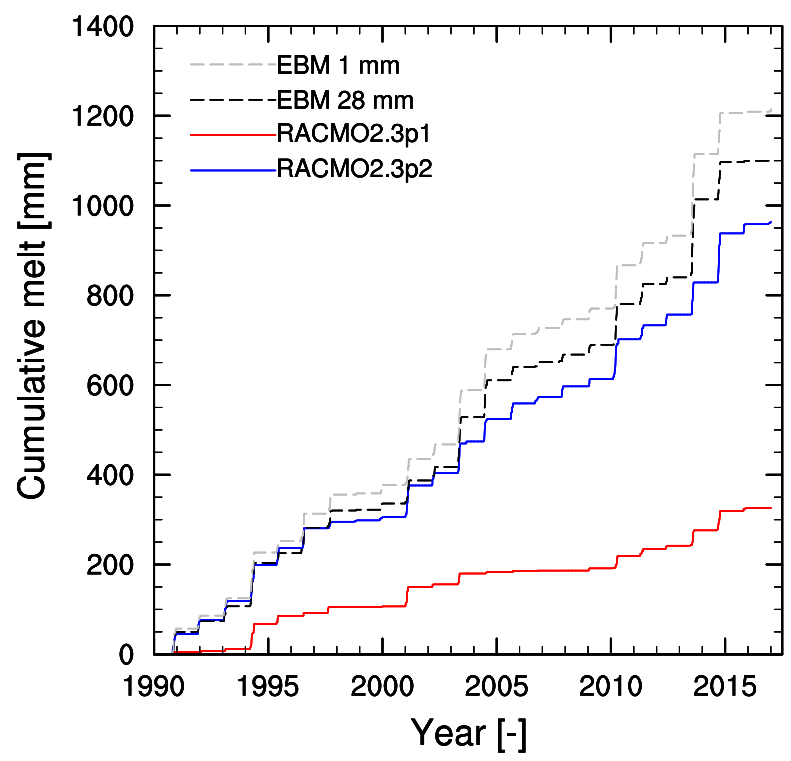

Figure 12. Cumulative melt at Neumayer calculated by the energy balance model (EBM) for 1990-2015 with roughness length $z_{0}=$ $28 \mathrm{~mm}$ (dashed black line), $z_{0}=1 \mathrm{~mm}$ (dashed grey line) and as modelled by RACMO2.3p2 (blue) and RACMO2.3p1 (red).

Table 4. Total Antarctic Peninsula integrated SMB mean 1979 2014 (the overlapping period for both model versions) values $\left[\mathrm{Gty}^{-1}\right]$ with interannual variability $\sigma$ : total (snow and rain) precipitation $\left(P_{\text {tot }}\right)$, snowfall $(\mathrm{SN})$, rainfall $(\mathrm{RA})$, total sublimation $\left(\mathrm{SU}_{\mathrm{tot}}\right)$, surface sublimation $\left(\mathrm{SU}_{\mathrm{S}}\right)$, drifting snow sublimation $\left(\mathrm{SU}_{\mathrm{ds}}\right)$, run-off $(\mathrm{RU})$, snowmelt $(M)$ and refrozen mass $(\mathrm{RF})$. All values calculated on the RACMO2.3p2/AP ice mask without Larsen B.

\begin{tabular}{lrrrrrrr}
\hline & \multicolumn{2}{c}{ RACMO2.3p2 } & & \multicolumn{2}{c}{ RACMO2.3p1 } & & p2-p1 \\
\cline { 2 - 3 } & mean & $\sigma$ & & mean & $\sigma$ & mean \\
\hline$P_{\text {tot }}$ & 377 & 58 & & 363 & 57 & $+14(0.4 \%)$ \\
$\mathrm{SN}$ & 374 & 57 & & 360 & 56 & $+14(0.4 \%)$ \\
$\mathrm{RA}$ & 3 & 1 & & 3 & 1 & 0 \\
$\mathrm{SU}_{\text {tot }}$ & 8 & 2 & & 11 & 2 & $-3(27 \%)$ \\
$\mathrm{SU}_{\mathrm{s}}$ & 3 & 0.5 & & 2 & 1 & $+1(5 \%)$ \\
$\mathrm{SU}$ & 5 & 0.5 & & 9 & 2 & $-4(44 \%)$ \\
$\mathrm{RU}$ & 1 & 2 & & 2 & 2 & 0 \\
$\mathrm{M}$ & 41 & 16 & & 31 & 12 & $+10(32 \%)$ \\
$\mathrm{RF}$ & 43 & 14 & & 33 & 12 & $+8(24 \%)$ \\
\hline $\mathrm{SMB}($ AP) & 366 & 58 & & 350 & 57 & $+16(4.5 \%)$ \\
$\mathrm{SMB}$ (WAP) & 287 & 48 & & 276 & 47 & $+11(3.9 \%)$ \\
$\mathrm{SMB}$ (EAP) & 79 & 10 & & 75 & 11 & $+4(5.3 \%)$ \\
\hline
\end{tabular}

glaciers where the SMB was formerly underestimated, but worsened for those where it was overestimated. RMSD worsened slightly, but the slope of the fit and the determination coefficient $r^{2}$ improved. Overall changes are small and fall well within the uncertainty/interannual variability of the discharge estimates/modelled SMB. 

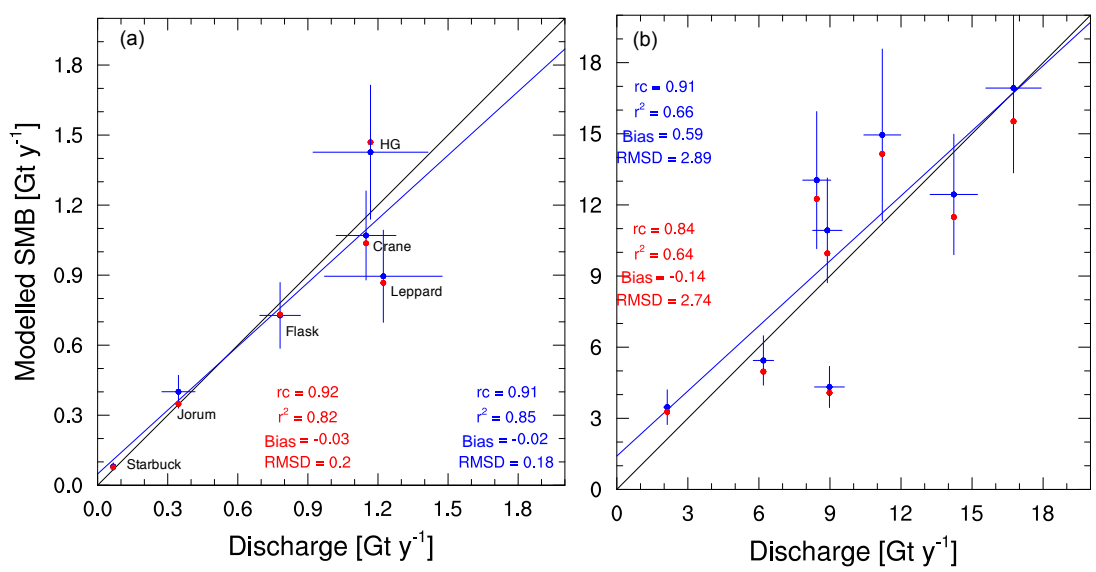

Figure 13. Modelled RACMO2.3p2/AP (blue) and RACMO2.3p1/AP (red) integrated average (1979-2016) SMB as a function of glacial discharge estimates from (a) the Larsen B embayment (Wuite et al., 2015) and (b) the George VI embayment (Hogg et al., 2017). Horizontal error bars represent the uncertainty in the discharge estimate, vertical bars the interannual variability of RACMO2.3.

\section{Remaining limitations and challenges}

\subsection{Clouds}

In this update of RACMO2.3 the near-surface climate in terms of the SEB and SMB has generally improved, but several limitations and challenges remain. For instance, changes in cloud scheme parameters governing the conversion of clouds into precipitation have altered the distribution and quantity of clouds over the ice sheet, which in turn has led to improvements in the near-surface climate, as presented in this study. Several of the variables related to the distribution of clouds over the East Antarctic plateau $\left(\mathrm{LW}_{\mathrm{d}}\right.$, precipitation and surface temperature $T_{\mathrm{S}}$ ) are now overestimated in the interior, albeit slightly so. Therefore, further improving these biases will require a different approach.

For instance, when the model is used at increasingly higher spatial resolution, it is important whether precipitation is handled prognostically by the model. While it is now assumed that precipitation reaches the surface instantaneously, ideally precipitation should be modelled as a prognostic variable in order to capture its fall time and horizontal displacement. This could significantly affect local precipitation patterns and hence SMB in regions of relatively high wind speeds and snowfall rates, such as the AP and the WAIS.

Several studies suggest that it is not necessarily the amount of cloud but the fractionation of cloud ice and cloud water content that is important for the radiative fluxes: King et al. (2015) showed that significant biases exist in relation to the ice/water content of clouds, and that a realistic simulation mainly requires accurate modelling of the presence or absence of clouds at a particular level in the atmosphere. Matus and L'Ecuyer (2017) and Lenaerts et al. (2017b) show that climate models typically exhibit significant biases in the simulation of clouds and radiation in the polar regions, and that future model developments should focus on the microphysi- cal properties of clouds and their radiative impact. We have also shown in Fig. 6 that, even though the simulation of the radiative fluxes has improved at the surface, RACMO2.3p2 considerably overestimates cloud ice and cloud water, suggesting that compensating errors exist due to a cloud radiation scheme that is not active enough. Further model improvement efforts should also focus on the surface layer turbulent mixing scheme (Van de Berg et al., 2006).

\subsection{Cold bias, meltwater and hydrostatic assumption}

The updated RACMO2.3/ANT and RACMO2.3/AP remain somewhat too cold at the surface, especially at lower elevations. This is partly due to biases in the SEB and cloud cover, but also likely due to the limited horizontal resolution. A limited horizontal resolution affects the near-surface winds, where biases influence the simulation of SHF and the associated mixing of warmer air to the surface. This limitation is addressed by the higher resolution in RACMO2.3/AP, but a further increase in horizontal resolution moves the model towards the limits of the hydrostatic assumption, and it would be necessary to resolve vertical accelerations and internal and gravity waves. A non-hydrostatic model formulation should be used if these features are to be explored further.

The cold bias in the model $10 \mathrm{~m}$ firn temperature mostly affects more temperate regions of the ice sheet (Fig. 5), which suggests that the bias could be related to the refreezing of meltwater. Meltwater percolates into the snow column, refreezes and raises snow temperature. Underestimating surface melt or neglecting meltwater penetration features (Harper et al., 2012; Ligtenberg et al., 2014) could result in too-low snow temperature. Another explanation is improper modelling of the albedo-melt feedback in regions of sustained local melt, such as the melt induced by foehn winds in the AP (Luckman et al., 2014; Van Wessem et al., 2016), or the wind-albedo interaction over blue-ice areas in DML 
(Lenaerts et al., 2016b). Further efforts to improve modelled melt fluxes should therefore focus on these features.

\section{Summary and conclusions}

In this study we evaluated the modelled Antarctic ice sheet (AIS) climate, surface mass balance (SMB) and surface energy balance (SEB) in RACMO2.3p2, the latest polar version of the regional atmospheric climate model RACMO2 (1979-2016). This model version is applied at $27 \mathrm{~km}$ horizontal resolution to the full AIS and at $5.5 \mathrm{~km}$ resolution to the Antarctic Peninsula (AP). Updates to the previous model version include additional upper-air relaxation by ERA-Interim reanalyses data, a revised topography, tuned parameters in the cloud scheme that generate more precipitation towards the AIS interior and modified snow properties reducing drifting snow sublimation and increasing simulated surface snowmelt. The updates in the $5.5 \mathrm{~km}$ AP simulation are similar but do not include a new topography or upper-air relaxation.

The updated model simulates more clouds towards the interior of the ice sheet, increasing downwelling longwave radiation and snowfall rates. Drifting snow sublimation rates decreased by $43 \%$ and surface snowmelt doubled. In total, these changes led to an integrated SMB for the ice sheet, including ice shelves and excluding the AP, of $2229 \mathrm{Gty}^{-1}$, with an interannual variability $\sigma=109 \mathrm{Gty}^{-1}$. We evaluated the model with various observational data, including in situ SMB observations (Favier et al., 2013), radarderived snow accumulation (Medley et al., 2013), CloudSatCALIPSO satellite observations (Van Tricht et al., 2016b), GRACE mass changes, horizontal drifting snow transport fluxes (Amory et al., 2017), QSCAT-satellite-derived melt fluxes (Trusel et al., 2013), AP glacial discharge estimates (Wuite et al., 2015; Hogg et al., 2017) and SEB data from AWSs. We find a significant improvement in simulated SEB and SMB over the ice sheet, in particular at lower elevations. The largest improvement is found in modelled surface snowmelt, which now compares considerably better with the QSCAT and Neumayer (indirect) melt observations. No significant changes are found for the $5.5 \mathrm{~km}$ model version: here, model results are comparable to earlier versions.

This study shows that the latest version of RACMO2 can be used for high-resolution future projections of AIS SMB and SEB. However, limitations remain, mostly related to the cloud microphysics, the horizontal resolution and partly to the meltwater percolation scheme in the snow model.
Data availability. The following data are available through the IMAU website: https://www.projects.science.uu.nl/iceclimate/ publications/data/2018/index.php:

- RACMO2.3p2 model data (this study). Contact: j.m.vanwessem@uu.nl,m.r.vandenbroeke@uu.nl.

- AWS SEB data (Van Wessem et al., 2014a). Contact: c.h.tijmreijmer@uu.nl, m.r.vandenbroeke@uu.nl.

- $10 \mathrm{~m}$ snow temperature observations (Van den Broeke, 2008; Van Wessem et al., 2014a). Contact: j.m.vanwessem@uu.nl, m.r.vandenbroeke@uu.nl.

- GRACE mass anomalies (this study). Contact: b.wouters@uu.nl.

- Drifting snow transport fluxes (Amory et al., 2017). Contact: charles.amory@uliege.be.

- CloudSat-CALIPSO (Van Tricht et al., 2016a). Contact: S.Lhermitte@ tudelft.nl.

- Antarctic Peninsula ice discharge (Wuite et al., 2015; Hogg et al., 2017).Contact: jan.wuite@enveo.at.

All other data used in this study are freely available by contacting the corresponding authors.

- In situ SMB observations (Favier et al., 2013). Contact: vincent.favier@univ-grenoble-alpes.fr. Available through http: //pp.ige-grenoble.fr/pageperso/favier/database.php; Quantarctica v3 http://quantarctica.npolar.no/.

- Neumayer melt fluxes (this study).Contact: s.l.jakobs@uu.nl, m.r.vandenbroeke@uu.nl.

- QuikSCAT melt fluxes (Trusel et al., 2013). Contact: trusel@rowan.edu. Available through Quantarctica v3 http:// quantarctica.npolar.no/.

- Accumulation radar-derived annual accumulation fluxes (Medley et al., 2015). Contact: brooke.c.medley@ nasa.gov.

- Kohnen radiosonde data (this study). Contact: gerit.birnbaum@awi.de.

Author contributions. JMW, BPYN, WJB and MB conceived this study, decided on the new model setting and performed the analysis and synthesis of the data sets. JMW performed the model simulations and led the writing of the manuscript. CA, GB, CLJ, KK SL, BM CHR, KT, LDT, BW and JW processed and provided observational data sets. JMW, BPYN, WJB, MB, JTML, SRML, CLJ, CHR, EM and LU contributed to the development of the model. All authors contributed to discussions on writing the manuscript.

Competing interests. The authors declare that they have no conflict of interest.

Acknowledgements. We acknowledge financial contributions made by the Netherlands Organization for Scientific Research (grant 866.15.201) and the Netherlands Earth System Science Center (NESSC). We thank the ECMWF for the use of their supercomputing facilities. Drifting snow observations in Adélie Land (Charles Amory) would not have been possible without the 
financial and logistical support of the French Polar Institute IPEV (programme CALVA-1013) Graphics and calculations were made using the NCAR Command Language (version 6.3.0, 2017).

Edited by: Xavier Fettweis

Reviewed by: Michael Lehning and one anonymous referee

\section{References}

Amory, C., Gallée, H., Naaim-Bouvet, F., Favier, V., Vignon, E., Picard, G., Trouvilliez, A., Piard, L., Genthon, C., and Bellot, H.: Seasonal Variations in Drag Coefficient over a SastrugiCovered Snowfield in Coastal East Antarctica, Bound.-Lay. Meteorol., 164, 107-133, https://doi.org/10.1007/s10546-017-02425, 2017.

Bamber, J. L., Gomez-Dans, J. L., and Griggs, J. A.: A new 1 km digital elevation model of the Antarctic derived from combined satellite radar and laser data - Part 1: Data and methods, The Cryosphere, 3, 101-111, https://doi.org/10.5194/tc-3-101-2009, 2009.

Barrand, N. E., Vaughan, D. G., Steiner, N., Tedesco, M., Kuipers Munneke, P., Van den Broeke, M. R., and Hosking, J. S.: Trends in Antarctic Peninsula surface melting conditions from observations and regional climate modeling, J. Geophys. Res.-Earth, 118, 315-330, https://doi.org/10.1029/2012JF002559, 2013.

Borsa, A. A., Moholdt, G., Fricker, H. A., and Brunt, K. M.: A range correction for ICESat and its potential impact on ice-sheet mass balance studies, The Cryosphere, 8, 345-357, https://doi.org/10.5194/tc-8-345-2014, 2014.

Cogley, J. G., Hock, R., Rasmussen, L. A., Arendt, A. A., Bauder, A., Braithwaite, R. J., Jansson, P., Kaser, G., Möller, M., Nicholson, L., and Zemp, M.: Glossary of Glacier Mass Balance and Related Terms, Tech. Rep. IHP-VII Technical Documents in Hydrology No. 86, IACS Contribution No. 2, UNESCO-IHP, Paris, 2011.

Dee, D. P., Uppala, S. M., Simmons, A. J., Berrisford, P., Poli, P., Kobayashi, S., Andrae, U., Balmaseda, M. A., Balsamo, G., Bauer, P., Bechtold, P., Beljaars, A. C. M., Van de Berg, L., Bidlot, J., Bormann, N., Delsol, C., Dragani, R., Fuentes, M., Geer, A. J., Haimberger, L., Healy, S. B., Hersbach, H., Hólm, E. V., Isaksen, L., Kållberg, P., Köhler, M., Matricardi, M., McNally, A. P., Monge-Sanz, B. M., Morcrette, J. J., Park, B. K., Peubey, C., de Rosnay, P., Tavolato, C., Thépaut, J. N., and Vitart, F.: The ERA-Interim reanalysis: configuration and performance of the data assimilation system, Q. J. Roy. Meteor. Soc., 137, 553-597, https://doi.org/10.1002/qj.828, 2011.

Déry, S. J. and Yau, M. K.: A Bulk Blowing Snow Model, Bound.-Lay. Meteorol., 93, 237-251, https://doi.org/10.1023/A:1002065615856, 1999.

DiMarzio, J., Brenner, A., Schutz, R., Shuman, C. A., and Zwally, H. J.: GLAS/ICESat $500 \mathrm{~m}$ laser altimetry digital elevation model of Antarctica, Tech. rep., 2007.

ECMWF-IFS: Part IV : Physical Processes (CY33R1), Tech. Rep. June, https://www.ecmwf.int/en/elibrary/ 9227-part-iv-physical-processes (last access: 29 October 2012), 2008.

Ettema, J., van den Broeke, M. R., van Meijgaard, E., van de Berg, W. J., Box, J. E., and Steffen, K.: Climate of the Greenland ice sheet using a high-resolution climate model - Part 1: Evaluation, The Cryosphere, 4, 511-527, https://doi.org/10.5194/tc-4511-2010, 2010.

Favier, V., Agosta, C., Genthon, C., Arnaud, L., Trouvillez, A., and Gallée, H.: Modeling the mass and surface heat budgets in a coastal blue ice area of Adelie Land, Antarctica, J. Geophys. Res., 116, F03017, https://doi.org/10.1029/2010JF001939, 2011.

Favier, V., Agosta, C., Parouty, S., Durand, G., Delaygue, G., Gallée, H., Drouet, A.-S., Trouvilliez, A., and Krinner, G.: An updated and quality controlled surface mass balance dataset for Antarctica, The Cryosphere, 7, 583-597, https://doi.org/10.5194/tc-7-583-2013, 2013.

Fettweis, X., Box, J. E., Agosta, C., Amory, C., Kittel, C., Lang, C., van As, D., Machguth, H., and Gallée, H.: Reconstructions of the 1900-2015 Greenland ice sheet surface mass balance using the regional climate MAR model, The Cryosphere, 11, 1015-1033, https://doi.org/10.5194/tc-11-1015-2017, 2017

Gallée, H., Trouvilliez, A., Agosta, C., Genthon, C., Favier, V., and Naaim-Bouvet, F.: Transport of Snow by the Wind: A Comparison Between Observations in Adélie Land, Antarctica, and Simulations Made with the Regional Climate Model MAR, Bound.Lay. Meteorol., 146, 133-147, https://doi.org/10.1007/s10546012-9764-z, 2013.

Genthon, C. and Krinner, G.: Antarctic surface mass balance and systematic biases in general circulation models, J. Geophys. Res., 106, 20653-20664, https://doi.org/10.1029/2001JD900136, 2001.

Greuell, W. and Konzelmann, T.: Numerical modelling of the energy balance and the englacial temperature of the Greenland Ice Sheet. Calculations for the ETH-Camp location (West Greenland, 1155 ma.s.1.), Global Planet. Change, 9, 91-114, https://doi.org/10.1016/0921-8181(94)90010-8, 1994.

Griggs, J. A. and Bamber, J. L.: A new $1 \mathrm{~km}$ digital elevation model of Antarctica derived from combined radar and laser data - Part 2: Validation and error estimates, The Cryosphere, 3, 113 123, https://doi.org/10.5194/tc-3-113-2009, 2009.

Harper, J., Humphrey, N., Pfeffer, W. T., Brown, J., and Fettweis, X.: Greenland ice-sheet contribution to sea-level rise buffered by meltwater storage in firn, Nature, 491, 240-3, https://doi.org/10.1038/nature11566, 2012.

Henderson, D. S., L'Ecuyer, T., Stephens, G., Partain, P., Sekiguchi, M., Henderson, D. S., L'Ecuyer, T., Stephens, G., Partain, P., and Sekiguchi, M.: A Multisensor Perspective on the Radiative Impacts of Clouds and Aerosols, J. Appl. Meteorol. Clim., 52, 853871, https://doi.org/10.1175/JAMC-D-12-025.1, 2013.

Hogg, A. E., Shepherd, A., Cornford, S. L., Briggs, K. H., Gourmelen, N., Graham, J. A., Joughin, I., Mouginot, J., Nagler, T., Payne, A. J., Rignot, E., and Wuite, J.: Increased ice flow in Western Palmer Land linked to ocean melting, Geophys. Res. Lett., 44, 4159-4167, https://doi.org/10.1002/2016GL072110, 2017.

King, J. C., Gadian, A., Kirchgaessner, A., Kuipers Munneke, P., Orr, A., Reijmer, C., Broeke, M. R., Van Wessem, J. M., and Weeks, M.: Validation of the summertime surface energy budgetof Larsen C Ice Shelf (Antarctica) as represented in three high-resolution atmospheric models, J. Geophysical Res.-Atmos., 120, 1335-1347, https://doi.org/10.1002/2014JD022604, 2015.

König-Langlo, G.: Basic measurements of radiation from Neumayer Station in the year 1999-2007, Alfred Wegener Institute, 
Helmholtz Center for Polar and Marine Research, Bremerhaven, PANGAEA, https://doi.org/10.1594/PANGAEA.819774, 2013.

Kuipers Munneke, P., Van den Broeke, M. R., Lenaerts, J. T. M., Flanner, M. G., Gardner, A. S., and Van de Berg, W. J.: A new albedo parameterization for use in climate models over the Antarctic ice sheet, J. Geophys. Res., 116, D05114, https://doi.org/10.1029/2010JD015113, 2011.

Kuipers Munneke, P., Ligtenberg, S. R. M., Van Den Broeke, M. R., and Vaughan, D. G.: Firn air depletion as a precursor of Antarctic ice-shelf collapse, J. Glaciol., 60, 205-214, https://doi.org/10.3189/2014JoG13J183, 2014.

Kuipers Munneke, P., Ligtenberg, S. R. M., Noël, B. P. Y., Howat, I. M., Box, J. E., Mosley-Thompson, E., McConnell, J. R., Steffen, K., Harper, J. T., Das, S. B., and van den Broeke, M. R.: Elevation change of the Greenland Ice Sheet due to surface mass balance and firn processes, 1960-2014, The Cryosphere, 9, 2009-2025, https://doi.org/10.5194/tc-9-2009-2015, 2015.

Langen, P. L., Fausto, R. S., Vandecrux, B., Mottram, R. H., and Box, J. E.: Liquid Water Flow and Retention on the Greenland Ice Sheet in the Regional Climate Model HIRHAM5: Local and Large-Scale Impacts, Front. Earth Sci., 4, 110, https://doi.org/10.3389/feart.2016.00110, 2017.

Lenaerts, J. T. M., van den Broeke, M. R., Déry, S. J., KönigLanglo, G., Ettema, J., and Munneke, P. K.: Modelling snowdrift sublimation on an Antarctic ice shelf, The Cryosphere, 4, 179190, https://doi.org/10.5194/tc-4-179-2010, 2010.

Lenaerts, J. T. M., Van den Broeke, M. R., Scarchilli, C., and Agosta, C.: Impact of model resolution on simulated wind, drifting snow and surface mass balance in Terre Adélie, East Antarctica, J. Glaciol., 58, 821-829, https://doi.org/10.3189/2012JoG12J020, 2012a.

Lenaerts, J. T. M., Van den Broeke, M. R., Van de Berg, W. J., Van Meijgaard, E., and Kuipers Munneke, P.: A new, high-resolution surface mass balance map of Antarctica (1979-2010) based on regional atmospheric climate modeling, Geophys. Res. Lett., 39, L04501, https://doi.org/10.1029/2011GL050713, 2012b.

Lenaerts, J. T. M., Smeets, C. J. P. P., Nishimura, K., Eijkelboom, M., Boot, W., van den Broeke, M. R., and van de Berg, W. J.: Drifting snow measurements on the Greenland Ice Sheet and their application for model evaluation, The Cryosphere, 8, 801814, https://doi.org/10.5194/tc-8-801-2014, 2014

Lenaerts, J. T. M., Lhermitte, S., Drews, R., Ligtenberg, S., Berger, S., Helm, V., Smeets, C., Broeke, M., Van de Berg, W., Van Meijgaard, E., Eijkelboom, M., Eisen, O., and Pattyn, F.: Meltwater produced by wind-albedo interaction stored in an East Antarctic ice shelf, Nat. Clim. Change, 7, 58-62, https://doi.org/10.1038/nclimate3180, 2016a.

Lenaerts, J. T. M., Vizcaino, M., Fyke, J., Van Kampenhout, L., and Van den Broeke, M. R.: Present-day and future Antarctic ice sheet climate and surface mass balance in the Community Earth System Model, Clim. Dynam., 47, 1367-1381, https://doi.org/10.1007/s00382-015-2907-4, 2016b.

Lenaerts, J. T. M., Ligtenberg, S. R. M., Medley, B., Van de Berg, W. J., Konrad, H., Nicolas, J. P., Van Wessem, J. M., Trusel, L. D., Mulvaney, R., Tuckwell, R. J., Hogg, A. E., and Thomas, E. R.: Climate and surface mass balance of coastal West Antarctica resolved by regional climate modelling, Ann. Glaciol., 1-13, https://doi.org/10.1017/aog.2017.42, 2017a.
Lenaerts, J. T. M., Van tricht, K., Lhermitte, S., and L'Ecuyer, T. S.: Polar clouds and radiation in satellite observations, reanalyses, and climate models, Geophys. Res. Lett., 44, 3355-3364, https://doi.org/10.1002/2016GL072242, 2017b.

Leuschen, C.: IceBridge Snow Radar L1B Geolocated Radar Echo Strength Profiles, Version 2, https://doi.org/10.5067/FAZTWP500V70, 2014.

Ligtenberg, S. R. M., Helsen, M. M., and van den Broeke, M. R.: An improved semi-empirical model for the densification of Antarctic firn, The Cryosphere, 5, 809-819, https://doi.org/10.5194/tc-5809-2011, 2011.

Ligtenberg, S. R. M., Van de Berg, W. J., Van den Broeke, M. R., Rae, J. G. L., and Van Meijgaard, E.: Future surface mass balance of the Antarctic ice sheet and its influence on sea level change, simulated by a regional atmospheric climate model, Clim. Dynam., 41, 867-884, https://doi.org/10.1007/s00382-013-1749-1, 2013.

Ligtenberg, S. R. M., Kuipers Munneke, P., and van den Broeke, M. R.: Present and future variations in Antarctic firn air content, The Cryosphere, 8, 1711-1723, https://doi.org/10.5194/tc8-1711-2014, 2014.

Lin, Y.-L., Farley, R. D., and Orville, H. D.: Bulk parameterization of the snow field in a cloud model, J. Clim. Appl. Meteorol., 22, 1065-1092, 1983.

Liu, H., Jezek, K., Li, B., and Zhao, Z.: Radarsat Antarctic Mapping Project Digital Elevation Model Version 2, Tech. rep., 2001.

Luckman, A., Elvidge, A., Jansen, D., Kulessa, B., Kuipers Munneke, P., King, J., and Barrand, N. E.: Surface melt and ponding on Larsen C Ice Shelf and the impact of föhn winds, Antarct. Sci., 26, 625-635, https://doi.org/10.1017/S0954102014000339, 2014.

Mann, G. W., Anderson, P. S., and Mobbs, S. D.: Profile measurements of blowing snow at Halley, Antarctica, J. Geophys. Res., 105, 24491-24508, https://doi.org/10.1029/2000JD900247, 2000.

Matus, A. V. and L'Ecuyer, T. S.: The role of cloud phase in Earth's radiation budget, J. Geophys. Res.-Atmos., 122, 25592578, https://doi.org/10.1002/2016JD025951, 2017.

Medley, B., Joughin, I., Das, S. B., Steig, E. J., Conway, H., Gogineni, S., Criscitiello, A. S., McConnell, J. R., Smith, B. E., Van den Broeke, M. R., Lenaerts, J. T. M., Bromwich, D. H., and Nicolas, J. P.: Airborne-radar and ice-core observations of annual snow accumulation over Thwaites Glacier, West Antarctica confirm the spatiotemporal variability of global and regional atmospheric models, Geophys. Res. Let., 40, 3649-3654, https://doi.org/10.1002/grl.50706, 2013.

Medley, B., Ligtenberg, S., Joughin, I., van den Broeke, M., Gogineni, S., and Nowicki, S.: Antarctic firn compaction rates from repeat-track airborne radar data: I. Methods, Ann. Glaciol., 56, 155-166, https://doi.org/10.3189/2015AoG70A203, 2015.

Noël, B., van de Berg, W. J., van Meijgaard, E., Kuipers Munneke, P., van de Wal, R. S. W., and van den Broeke, M. R.: Evaluation of the updated regional climate model RACMO2.3: summer snowfall impact on the Greenland Ice Sheet, The Cryosphere, 9, 1831-1844, https://doi.org/10.5194/tc-9-1831-2015, 2015.

Noël, B., van de Berg, W. J., Machguth, H., Lhermitte, S., Howat, I., Fettweis, X., and van den Broeke, M. R.: A daily, $1 \mathrm{~km}$ resolution data set of downscaled Greenland ice sheet surface 
mass balance (1958-2015), The Cryosphere, 10, 2361-2377, https://doi.org/10.5194/tc-10-2361-2016, 2016.

Noël, B., van de Berg, W. J., van Wessem, J. M., van Meijgaard, E., van As, D., Lenaerts, J. T. M., Lhermitte, S., Kuipers Munneke, P., Smeets, C. J. P. P., van Ulft, L. H., van de Wal, R. S. W., and van den Broeke, M. R.: Modelling the climate and surface mass balance of polar ice sheets using RACMO2 Part 1: Greenland (1958-2016), The Cryosphere, 12, 811-831, https://doi.org/10.5194/tc-12-811-2018, 2018.

Palerme, C., Genthon, C., Claud, C., Kay, J. E., Wood, N. B., and L'Ecuyer, T.: Evaluation of current and projected Antarctic precipitation in CMIP5 models, Clim. Dynam., 48, 225-239, https://doi.org/10.1007/s00382-016-3071-1, 2017.

Reijmer, C. H. and Hock, R.: Internal accumulation on Storglaciären, Sweden, in a multi-layer snow model coupled to a distributed energy- and mass-balance model, J. Glaciol., 54, 61-72, 2008.

Reijmer, C. H. and Oerlemans, J.: Temporal and spatial variability of the surface energy balance in Dronning Maud Land, East Antarctica, J. Geophys. Res., 107, 4759, https://doi.org/10.1029/2000JD000110, 2002.

Reijmer, C. H., Van Meijgaard, E., and Van den Broeke, M. R.: Evaluation of temperature and wind over Antarctica in a Regional Atmospheric Climate Model using 1 year of automatic weather station data and upper air observations, J. Geophys. Res., 110, D04103, https://doi.org/10.1029/2004JD005234, 2005.

Rignot, E.: Accelerated ice discharge from the Antarctic Peninsula following the collapse of Larsen B ice shelf, Geophys. Res. Lett., 31, L18401, https://doi.org/10.1029/2004GL020697, 2004.

Rignot, E., Bamber, J. L., Van den Broeke, M. R., Davis, C., Li, Y., Van de Berg, W. J., and Van Meijgaard, E.: Recent Antarctic ice mass loss from radar interferometry and regional climate modelling, Nat. Geosci.e, 1, 106-110, https://doi.org/10.1038/ngeo102, 2008.

Rignot, E., Mouginot, J., and Scheuchl, B.: Antarctic grounding line mapping from differential satellite radar interferometry, Geophys. Res. Lett., 38, L10504, https://doi.org/10.1029/2011GL047109, 2011a.

Rignot, E., Mouginot, J., Scheuchl, B.: Ice Flow of the Antarctic Ice Sheet, Science, 333, 1427-1430, 2011 b.

Rignot, E., Velicogna, I., Van den Broeke, M. R., Monaghan, A., and Lenaerts, J. T. M.: Acceleration of the contribution of the Greenland and Antarctic ice sheets to sea level rise, Geophys. Res. Lett., 38, L05503, https://doi.org/10.1029/2011GL046583, 2011c.

Scambos, T., Fricker, H. A., Liu, C.-C., Bohlander, J., Fastook, J., Sargent, A., Massom, R., and Wu, A.-M.: Ice shelf disintegration by plate bending and hydro-fracture: Satellite observations and model results of the 2008 Wilkins ice shelf break-ups, Earth Planet. Sc. Lett., 280, 51-60, https://doi.org/10.1016/j.epsl.2008.12.027, 2009.

Shepherd, A., Ivins, E. R., A, G., Barletta, V. R., Bentley, M. J., Bettadpur, S., Briggs, K. H., Bromwich, D. H., Forsberg, R., Galin, N., Horwath, M., Jacobs, S., Joughin, I., King, M. A., Lenaerts, J. T. M., Li, J., Ligtenberg, S. R. M., Luckman, A., Luthcke, S. B., McMillan, M., Meister, R., Milne, G., Mouginot, J., Muir, A., Nicolas, J. P., Paden, J., Payne, A. J., Pritchard, H., Rignot, E., Rott, H., Sorensen, L. S., Scambos, T. A., Scheuchl, B., Schrama, E. J. O., Smith, B., Sundal, A. V., Van Angelen,
J. H., Van de Berg, W. J., Van den Broeke, M. R., Vaughan, D. G., Velicogna, I., Wahr, J., Whitehouse, P. L., Wingham, D. J., Yi, D., Young, D., and Zwally, H. J.: A Reconciled Estimate of Ice-Sheet Mass Balance, Science, 338, 1183-1189, https://doi.org/10.1126/science.1228102, 2012.

Trouvilliez, A., Naaim-Bouvet, F., Genthon, C., Piard, L., Favier, V., Bellot, H., Agosta, C., Palerme, C., Amory, C., and Gallée, H.: A novel experimental study of aeolian snow transport in Adelie Land (Antarctica), Cold Reg. Sci. Technol., 108, 125138, https://doi.org/10.1016/j.coldregions.2014.09.005, 2014.

Trusel, L. D., Frey, K. E., Das, S. B., Kuipers Munneke, P., and van den Broeke, M. R.: Satellite-based estimates of Antarctic surface meltwater fluxes, Geophys. Res. Lett., 40, 6148-6153, https://doi.org/10.1002/2013GL058138, 2013.

UCAR/NCAR/CISL/VETS: The NCAR Command Language (Version 6.3.0) [Software], (2017) https://doi.org/10.5065/D6WD3XH5, 2017.

Undén, P., Rontu, L., Jarvinen, H., Lynch, P., Calvo, J., Cats, G., Cuxart, J., Eerola, K., Fortelius, C., Garcia-moya, J., Jones, C., Lenderlink, G., Mcdonald, A., Mcgrath, R., and Navascues, B.: HIRLAM-5 Scientific Documentation, Tech. Rep. December, Swedish Meteorology and Hydrology Institute, 2002.

Välisuo, I., Vihma, T., and King, J. C.: Surface energy budget on Larsen and Wilkins ice shelves in the Antarctic Peninsula: results based on reanalyses in 1989-2010, The Cryosphere, 8, 15191538, https://doi.org/10.5194/tc-8-1519-2014, 2014.

van de Berg, W. J. and Medley, B.: Brief Communication: Upper-air relaxation in RACMO2 significantly improves modelled interannual surface mass balance variability in Antarctica, The Cryosphere, 10, 459-463, https://doi.org/10.5194/tc10-459-2016, 2016.

Van de Berg, W. J., Van den Broeke, M. R., Reijmer, C. H., and Van Meijgaard, E.: Reassessment of the Antarctic surface mass balance using calibrated output of a regional atmospheric climate model, J. Geophys. Res., 111, D11104, https://doi.org/10.1029/2005JD006495, 2006.

Van den Broeke, M., König-Langlo, G., Picard, G., Kuipers Munneke, P., and Lenaerts, J. T. M.: Surface energy balance, melt and sublimation at Neumayer Station, East Antarctica, Antarct. Sci., 22, 87-96, https://doi.org/10.1017/S0954102009990538, 2009.

Van den Broeke, M. R.: Depth and density of the Antarctic firn layer, Arct. Antarct. Alp. Res., 40, 432-438, https://doi.org/10.1657/1523-0430(07-021)[Broeke]2.0.CO;2, 2008.

Van den Broeke, M. R., Reijmer, C. H., and Van As, D.: Seasonal cycles of Antarctic surface energy balance from automatic weather stations, Ann. Glaciol., 41, 131-139, https://doi.org/10.3189/172756405781813168 2005a.

Van den Broeke, M. R., Van As, D., Reijmer, C. H., and Van de Wal, R. S. W.: Sensible heat exchange at the Antarctic snow surface: a study with automatic weather stations, Int. J. Climatol., 25, 1081-1101, https://doi.org/10.1002/joc.1152,2005b.

Van Lipzig, N. P. M., Van Meijgaard, E., and Oerlemans, J.: The spatial and temporal variability of the surface mass balance in Antarctica: results from a regional atmospheric climate model, Int. J. Climatol., 22, 1197-1217, https://doi.org/10.1002/joc.798, 2002 . 
Van Tricht, K., Lhermitte, S., Gorodetskaya, I. V., and van Lipzig, N. P. M.: Improving satellite-retrieved surface radiative fluxes in polar regions using a smart sampling approach, The Cryosphere, 10, 2379-2397, https://doi.org/10.5194/tc-10-2379-2016, 2016 a.

Van Tricht, K., Lhermitte, S., Lenaerts, J. T. M., Gorodetskaya, I. V., L'Ecuyer, T. S., Noël, B., van den Broeke, M. R., Turner, D. D., and van Lipzig, N. P. M.: Clouds enhance Greenland ice sheet meltwater runoff., Nat. Commun., 7, 10266, https://doi.org/10.1038/ncomms10266, 2016b.

van Wessem, J. M., Reijmer, C. H., Lenaerts, J. T. M., van de Berg, W. J., van den Broeke, M. R., and van Meijgaard, E.: Updated cloud physics in a regional atmospheric climate model improves the modelled surface energy balance of Antarctica, The Cryosphere, 8, 125-135, https://doi.org/10.5194/tc-8-125-2014, 2014a.

Van Wessem, J. M., Reijmer, C. H., Morlighem, M., Mouginot, J., Rignot, E., Medley, B., Joughin, I., Wouters, B., Depoorter, M. A., Bamber, J. L., Lenaerts, J. T. M., Van De Berg, W. J., Van Den Broeke, M. R., and Van Meijgaard, E.: Improved representation of East Antarctic surface mass balance in a regional atmospheric climate model, J. Glaciol., 60, 761-770, https://doi.org/10.3189/2014JoG14J051, 2014b.

Van Wessem, J. M., Reijmer, C. H., Van de Berg, W. J., Van den Broeke, M. R., Cook, A. J., Van Ulft, L. H., and Van Meijgaard, E.: Temperature and Wind Climate of the Antarctic Peninsula as Simulated by a High-Resolution Regional Atmospheric Climate Model, J. Climate, 28, 7306-7326, https://doi.org/10.1175/JCLID-15-0060.1, 2015. van Wessem, J. M., Ligtenberg, S. R. M., Reijmer, C. H., van de Berg, W. J., van den Broeke, M. R., Barrand, N. E., Thomas, E. R., Turner, J., Wuite, J., Scambos, T. A., and van Meijgaard, E.: The modelled surface mass balance of the Antarctic Peninsula at $5.5 \mathrm{~km}$ horizontal resolution, The Cryosphere, 10, 271285,https://doi.org/10.5194/tc-10-271-2016, 2016.

Winkelmann, R., Levermann, a., Martin, M. a., and Frieler, K.: Increased future ice discharge from Antarctica owing to higher snowfall, Nature, 492, 239-42, https://doi.org/10.1038/nature11616, 2012.

Wuite, J., Rott, H., Hetzenecker, M., Floricioiu, D., De Rydt, J., Gudmundsson, G. H., Nagler, T., and Kern, M.: Evolution of surface velocities and ice discharge of Larsen B outlet glaciers from 1995 to 2013, The Cryosphere, 9, 957-969, https://doi.org/10.5194/tc-9-957-2015, 2015.

Zwally, H. J., Giovinetto, M. B., Beckley, M. A., and Saba, J. L.: Antarctic and Greenland Drainage Systems, 2012. 